\title{
Spatially explicit economic effects of non- susceptible pests' invasion on Bt maize
}

\section{Article}

\section{Accepted Version}

Creative Commons: Attribution-Noncommercial-No Derivative Works 4.0

Catarino, R., Areal, F., Park, J. and Parisey, N. (2019) Spatially explicit economic effects of non-susceptible pests' invasion on Bt maize. Agricultural Systems, 175. pp. 22-33. ISSN 0308521X doi: https://doi.org/10.1016/j.agsy.2019.05.008 Available at https://centaur.reading.ac.uk/83872/

It is advisable to refer to the publisher's version if you intend to cite from the work. See Guidance on citing.

To link to this article DOI: http://dx.doi.org/10.1016/j.agsy.2019.05.008

Publisher: Elsevier

All outputs in CentAUR are protected by Intellectual Property Rights law, including copyright law. Copyright and IPR is retained by the creators or other copyright holders. Terms and conditions for use of this material are defined in the End User Agreement.

\section{www.reading.ac.uk/centaur}

\section{CentAUR}

Central Archive at the University of Reading

Reading's research outputs online 
1 Title: Spatially explicit economic effects of non-susceptible pests' invasion on $B t$ maize

2 Authors: Rui Catarino**, Francisco Areal ${ }^{\mathrm{a}}$, Julian Park ${ }^{\mathrm{a}}$ and Nicolas Parisey

3 Affiliations:

${ }^{a}$ Agri-food Economics and Social Sciences Research Division, School of Agriculture, Policy and Development, University of Reading, Reading, UK national de la recherche agronomique, Rennes, France

8 Running title: Spatial economics effects of pest invasion in $B t$

9 Corresponding author:

Rui Catarino

Present address: Laboratoire Agronomie et Environnement, INRA, 28 Rue de Herrlisheim, F-

Conflict of Interest statement: The manuscript's authors certify that they have NO affiliations with or involvement in any organization or entity with any financial interest, or non-financial interest (such as personal or professional relationships, affiliations, knowledge or beliefs) in the subject matter or materials discussed in this manuscript. 


\section{$\underline{\text { Abstract }}$}

Maize expressing the Bacillus thuringiensis Cry1 Ab toxin (Bt maize) provides a more effective control of corn borers than the use of insecticides. Yet, the spatial expansion of $B t$ maize may offer ideal ecological conditions for the development and spread of secondary pests, i.e. pests not susceptible to the expressed toxin. This paper develops a bio-economic, spatially explicit population model to analyse the spread and economic consequences of a secondary pest outbreak. Results show that the present use and even an eventual expansion of $B t$ maize can be economically and environmentally advantageous, as it would decrease insecticide usage intensity. However, we show that caution is required when considering its widespread use. If a pest outbreak is not identified and dealt with at an early stage, it could lead to severe economic impacts even if insecticides are used in combination with the $B t$ maize. We further discuss potential policy and subsequent management strategies to address this issue.

Keywords: Bacillus thuringiensis; Spatially explicit; Bioeconomic model; Bt maize; Pest management; Population dynamics; Secondary pest.

\section{Introduction}

Commercialized genetically engineered insect resistant (GEIR) crops have provided economic and environmental benefits in relation to pest control (Areal et al., 2013; Areal and Riesgo, 2015). Presently, the only GEIR crop allowed for cultivation in the European Union (EU-28) is Bt (Bacillus thuringiensis) maize which contains the transformation event MON810 (Monsanto Company) and expresses Bt Cry1 Ab toxin (Devos et al., 2014). The economic benefits associated with a significant decrease in insecticide application compared to the growth of conventional maize (Areal et al., 2013; Areal and Riesgo, 2015; Gómez-Barbero et al., 2008) are the main reason behind the rapid adoption of Bt maize among Spanish farmers (James, 2014). So far this technology has provided an efficient control of two primary pests, the Mediterranean Corn Borer, Sesamia nonagrioides Lefebvre (Lepidoptera: Noctuidae) and the European Corn Borer, Ostrinia nubilalis Hübner (Lepidoptera: Crambidae) (Farinos et al., 2011; González-Núñez et al., 2000). It was estimated that in European countries where $B t$ maize is not used yet (or where it is prohibited), farmers maybe foregoing benefits of between 157 to 334 
million Euros per year (Park et al., 2011). Additionally, due to the high specificity and efficiency of $B t$ Cry toxins toward key target pest species, it is generally accepted that any eventual detrimental impact on non-target organisms is lower for $B t$ crops than for conventional crops treated with broad-spectrum insecticides (Meissle and Lang, 2005; Stephens et al., 2012). However, and regardless of their largescale adoption (about 1\% of the world's total maize hectarage (James, 2014)), GEIR crops remain a controversial technology dividing the scientific community (Kolseth et al., 2015; Lövei et al., 2009). This paper focuses on one aspect of the GEIR debate: regional economic impact (i.e. economic damage to the crop) of insect pests not susceptible to the expressed toxin of a genetically engineered (GE) crop, henceforth secondary pests, taking into account the landscape structure and farm pest management strategy.

The colonization of agro-ecological systems by pests is a well-established global issue that can lead to considerable economic and ecological damage (Pimentel et al., 2001). Pest species have diverse mechanisms of introduction and establishment within a new agroecosystem which are generally influenced by habitat suitability and anthropogenic activities (Liebhold et al., 2016). They may take opportunistic advantage of altered ecosystems and land-use patterns, such as the expansion of monocultures (Tilman, 1999). In this context, there are concerns that changes in cultural practices (e.g. conservation tillage and reduced insecticide use) due to the adoption of $B t$ maize might contribute to a change in species dynamics (Hutchison et al., 2010). For instance, insect species that are not susceptible to the expressed toxin can increase in number and develop into secondary pests, causing significant damage to the crop (Catarino et al., 2016, 2015). Two of the best-known cases related to GEIR maize cropping are the Western Bean Cutworm, Striacosta albicosta Smith (Lepidoptera: Noctuidae), a noctuid moth native to West and Central America (Eichenseer et al., 2008) and the Western Corn Rootworm, Diabrotica virgifera LeConte (Coleoptera: Chrysomelidae), native to South and Central America $(\mathrm{He}, 2002)$. These species are considered important secondary pests as they show low susceptibility to most transgenic maize events currently commercialized (Eichenseer et al., 2008). In the US and Canada the expansion of the western bean cutworm, which began in the mid 1990's, may be 
Field trials have shown that transgenic crops expressing Cry1Ab and Cry9C toxins had larger populations of Western Bean Cutworm compared to conventional maize (Dorhout and Rice, 2010; Eichenseer et al., 2008; Lindroth et al., 2012). Researchers have recently suggested that a similar case could develop in Spain with an increase in True Armyworm populations, [Mythimna (Pseudaletia) unipuncta Haworth (Lepidoptera: Noctuidae)] (Pérez-Hedo et al., 2013, 2012), a pest capable of causing severe crop losses which is not susceptible to Bt Cry toxins. The increase of transgenic maize could affect the population dynamics of true armyworms due to the high efficiency of $B t$ maize against target pests (Eizaguirre et al., 2009; López et al., 2008).

Here we used a bio-economic spatially explicit population model to analyse the economic consequences of an outbreak of true armyworm, a possible secondary pest of maize in Spain. Dynamic bio-economic models that deal with the agro-economic impact of multiple insect pests (Aadland et al., 2014) or that estimate the removal costs of invasive species are not common in the literature (Jardine and Sanchirico, 2018). The research reported here builds on the model framework developed by Catarino et al (2016). Our analysis develops the existing bio-economic modelling literature by 1) incorporating spatial aspects (i.e. agricultural land use type); and 2) incorporating multi-pest species spatial interaction and spread. The flexible modelling approach presented here could be used for other pest species and in different regions. The methodology and results presented in the paper provide improved insights into pest spatial interrelations and their economic impact under different scenarios where $B t$ crops are grown. We provide recommendations for the development of policy/management strategies aimed at avoiding situations in which the eradication of the invading species is not feasible, as well as disclosing needs for further research.

\section{Methods}

The modelling framework from Catarino et al (2016) was adapted and expanded to incorporate spatial aspects, combining theories of movement ecology, population dynamics, statistics, and estimation of economic impacts and farmers' decisions. The model was used to analyse the economic impacts accrued from the spatial movement and spread of a primary pest, the Mediterranean corn borer, 
and a secondary pest, the true armyworm, to maize farmers in Aragon, Spain. Both species are affected by abiotic, such as insecticides (Albajes et al., 2002), biotic factors, such as interspecific competition (Eizaguirre et al., 2009) and natural enemies (Alexandri and Tsitsipis, 1990; Eizaguirre and Pons, 2003), and the land-use effect (Eizaguirre and Fantinou, 2012; Menalled et al., 1999). The spatial model is developed in the context of the Aragon region in Spain using up-to-date landscape information, based on individually managed properties with a variety of uses. Each manager's control decisions (e.g. insecticide use and maize variety) indirectly impacts his/her neighbours' decisions, by affecting the spread of species across boundaries. It is assumed that farmers make control decisions based only on pest damage occurring on their own land (i.e. there is no publically or governmentally funded detection or control system) aiming to maximize their individual net present value (NPV) in the long-term (25 years).

\subsection{Study context}

The only GE crop allowed for cultivation in Europe is $B t$ maize, which contains the transformation event MON810 (Monsanto Company), expressing Cry1 Ab Bt toxin (Devos et al., 2014). Spain is by far the largest GE technology adopter, 92\% of the total GE maize in the EU is grown there (James, 2014). Maize is the second most abundant crop in Spain on an area basis, exceeded only by wheat (MAGRAMA, 2013). In 2012, the areas of maize cultivated in the main maize-growing regions, Castile, Estremadura and Aragon were 105.061, 60.643 and 55.484 hectares respectively (MAGRAMA, 2013). In these areas, maize is almost entirely cropped in an intensive monoculture regime, which, allied with the Mediterranean climate conditions, favours the development of pests (Eizaguirre and Fantinou, 2012; Vasileiadis et al., 2011). The most worrying agents causing high control costs are corn borers and some secondary pests (Eizaguirre and Fantinou, 2012; Lopez et al., 2000). Traditionally these pests have been controlled by cultural practices and broad-spectrum insecticides (organophosphates and synthetic pyrethroids). The Aragon region is one of the 17 autonomous Spanish communities, is situated in the Ebro basin in north-eastern Spain with an area of $47.720 \mathrm{~km}^{2}$. Of the 55.484 hectares of maize planted in Aragon in 2012, 75\% was $B t$ maize, representing a third of the total $B t$ maize produced in Spain 
(James, 2014). The high adoption is likely to be due to the farmers' satisfaction with pest control and the general positive economic returns of the GE variety (Areal et al., 2013; Areal and Riesgo, 2015).

\subsection{The case study species}

There is broad consensus that the Mediterranean corn borer is one of the most important maize pest in countries around the Mediterranean basin, including Spain (Farinos et al., 2011; González-Núñez et al., 2000). In conventional maize cropping, Mediterranean corn borer control through the use of insecticides is only moderately effective since larval development occurs mainly inside the stalk (Albajes et al., 2002). Additionally, the expansion of maize production areas in monoculture system in the past decades (Eizaguirre and Fantinou, 2012) has also favoured its prevalence. In Spain, the true armyworm is considered to be an important secondary pest causing occasional but severe damage to maize (Eizaguirre et al., 2009; Pérez-Hedo et al., 2013, 2012). Attempts to analyse and predict true armyworm outbreaks have been constrained by the great capacity for flight of adults (moths), rapid reproduction rate, its explosive expansion and unpredictable behaviour (Hill and Atkins, 1982; Lopez et al., 2000). Additionally, under normal conditions the Mediterranean corn borer tends to outcompete the true armyworm (Eizaguirre et al., 2009). In this context, the increase of transgenic maize could affect the population dynamics of this secondary Lepidopteran pest due to the high efficiency of $B t$ maize against its target pests (López et al., 2008; Pérez-Hedo et al., 2012). True armyworms would be able to take advantage of the absence of major corn borers. These species are representative of the problem of secondary pest explored in this paper. Both species compete for the same food resource, maize, and the Mediterranean corn borer, although biologically more resilient than the true armyworm, is effectively controlled by $B t$ maize. For further information on both species description and relevance to maize production, the reader is directed to (Catarino et al., 2016).

\subsection{Modelling framework}


The model developed requires knowledge of certain key economic and ecological parameters, namely flight and reproduction capacity parameters of pests, the geographic location and region of the maize fields and the economic maize production parameters for the base year of 2012 (Tables I and II). Five scenarios with different $B t$ maize adoption ratios are examined here. The first scenario (S1) represents the actual maize area for the year 2012. Scenario 1 is based on the actual proportions of areas of $B t$ and conventional maize and is evaluated under three different pest management strategies (PMS): PMS1, insecticides are used in both maize systems; PMS2, insecticides are only used in conventional maize, and; PMS3, no insecticides are used. The four other scenarios assume different $B t /$ conventional maize ratios to the areas recorded in 2012: S2, no $B t$ maize is cropped; S3, $B t$ maize area is reduced by 50\%; S4, Bt maize area is $50 \%$ greater than recorded in 2012 and; S5, all cropped maize is $B t$ maize. Scenario 1 with PMS1 is used as the basis of comparison for the other scenarios.

\subsubsection{Model simulations}

The five different adoption scenarios were assessed in order to estimate the influence of $B t$ maize on the spread of a secondary pest and the consequent economic impacts for Aragon's maize farmers. A total of seven cases were analysed including the three PMSs of S1. To infer the influence of the landscape on the invasion process, each of the cases were simulated a 100 times. The simulations showed an acceptable convergence of the mean of the total producers' welfare losses and cumulative area invaded over 25 years (i.e. no significant difference was found in these values when the number of simulations was increased). The population of Mediterranean corn borers, as primary and endemic pest in Aragon, at $\boldsymbol{T}=0$ is considered to be $10 \%$ of its carrying capacity and present in all fields favourable to reproduction (Fig. 1a). It is assumed that true armyworms are introduced at a randomized location of favourable habitat, spreading to neighbouring cells. The initial population of the true armyworm population, i.e. at the moment of outbreak with $T=0$, is characterised by 2D 5x5 grid sized kernel (Fig. 1b). The kernel represents the outbreak area: at the centre true armyworm's density is considered to be $10 \%$ of its carrying capacity, and the surrounding cells follow a Cauchy distribution, usually used in the study of biological invasion (Kot et al., 1996), containing a proportion of individuals in relation to the 
centre (Fig. 1b). After a local sensitivity analysis, no significance difference (using the Tukey HSD posthoc test) was found between the different kernel sizes $(3 \times 3,5 \times 5,7 \times 7$ and $9 \times 9$, simulated each case 25 times for PMS1). Natural enemies for both species are present evenly throughout the landscape, being only affected by insecticide applications. In short, both species spread in all possible directions dependent on the local dynamics in each cell that are determined by the each species density, the landscape characteristics, natural enemies, pesticides applications and competition between and within species (see below local and spatial pest dynamics subheadings).

The parameters for the economic and ecological components of the model are presented in Table II. The model was written and numerically solved with R software (R Core Team, 2014) with support from the "deSolve" (Soetaert et al., 2015), "RcppDE” (Eddelbuettel, 2015), "Raster" (Hijmans, 2014) and "mgcv" packages (Simon Wood, 2016). The model was constructed as a reaction-diffusion system of two coupled partial differential equations, characterising the spatial population dynamics of the two pests. The reaction term describes the population growth and mortality at time $t$, and the diffusion term describes the spread of populations in space. The overall scheme use operator splitting between the reaction terms and the diffusion terms. The model was solved numerically by operator splitting, with the Runge-Kutta 4th order method solving the reaction term and the Alternating Direction Implicit scheme solving the diffusion term (as in Bourhis et al. (2015); see also Hundsdorfer and Verwer (2013) for details on those methods). The total area invaded (TAI) after $\boldsymbol{T}$ years represents the total colonized area at time $\boldsymbol{T}$, i.e. $\boldsymbol{T} \boldsymbol{A I}=\sum_{\boldsymbol{t}=\mathbf{0}}^{T} A_{t}$. Where At is the colonized area at time $\mathrm{t}, \mathrm{T}$ is the length of the observation period.

\subsubsection{Aragon landscape}

The Aragon landscape is represented with a grid derived from an ASCII raster taken from the CORINE 2006 Land Cover dataset (Agency European Environment, 2010). Maize field data were directly obtained from the Aragon regional government statistics and explicitly incorporated in the CORINE map (Fig. 2a). The original regional landscape was aggregated for the relevant land cover types with a spatial resolution of $500 \times 500$ m, i.e. 25 ha (Fig. 2 b), composed of 11 different categories 
(Table I). When aggregating the landscape fields, which was necessary for computation practicalities,

211 the total modelled maize area did not significantly differ from real data, only $4 \%$ of spatial maize

212 information was lost. The domain $\mathbf{\Omega}$ represents the whole simulation area, $(\mathbf{x}, \mathbf{y}) \in \mathbf{\Omega}$, discretized as a $483 \times 684\left(\boldsymbol{\Omega}_{x}, \boldsymbol{\Omega}_{y}\right)$ matrix, from which 855 and 1279 cells are categorised as conventional $\left(\boldsymbol{\Omega}_{\text {Conv }}\right)$ and $B t$ maize $\left(\boldsymbol{\Omega}_{\boldsymbol{B} t}\right)$, respectively. The effects of the spatial heterogeneity on each species influences survival and movement. Based on expert knowledge and taking into consideration the resource availability, the landscape was categorised into (see Table I): i) areas of favourable habitat, i.e. where the species can reproduce, colonize and disperse; and ii) hostile habitat, where reproduction and dispersion are impeded. evaluated taking into consideration the implications of different pest management decisions over a time interval $[\mathbf{0}, \boldsymbol{T}]$. We chose a long-term timeframe to allow pests to effectively disperse throughout the space. The discount profit at time $\boldsymbol{t}$, based on a discount rate of $5 \%(\boldsymbol{\delta})$, results from the sum of the total revenue $(\Pi=p Y(Z, \Lambda))$ subject to the damage caused by both pests $(\boldsymbol{\Lambda})$, subtracting the costs of noninsecticide inputs (i.e. labour, seeds, fertilizers etc.) and the insecticide costs, represented by $\boldsymbol{p}_{\boldsymbol{m}} \boldsymbol{Z}$ and $\boldsymbol{p}_{w} \boldsymbol{W}$ respectively, per field. Thus, letting $\boldsymbol{p}_{c}$ denote output price, $\boldsymbol{p}_{\boldsymbol{m}}$ the cost of conventional and of $B t$ maize inputs unrelated to damage control $(\boldsymbol{m}=\{\boldsymbol{B t}, \boldsymbol{C o n v}\}), \boldsymbol{p}_{w}$ the price of a unit of insecticide $(\mathbf{w})$, the bio-economic spatially explicit population model becomes:

$$
N P V_{\Omega, T}=\left(\sum_{C o n v=1}^{855} \Omega_{C o n v}+\sum_{B t=1}^{1279} \Omega_{B t}\right) \int_{0}^{T} e^{-\delta t}\left\{\mathrm{p}_{c} \Pi(\mathrm{Z}, \Lambda)-\left(\mathrm{p}_{m} \mathrm{Z}+\mathrm{p}_{w} \mathrm{~W}\right)\right\} d t
$$

The damage-abating role of insecticide is taken into account explicitly in the production function, through an asymmetric treatment of "productive" inputs $(\mathbf{Z})$ and "damage-abating" insecticide $(\boldsymbol{w}), \boldsymbol{Y}=$ $\boldsymbol{\Pi}(\boldsymbol{Z}, \boldsymbol{\Lambda})$, where $\boldsymbol{Y}$ is the actual output. The damage-abatement function, $\boldsymbol{\Lambda}$, represents the role of 
insecticide in the model, which does not have the potential to increase the output but indirectly mitigates yield losses through pest elimination.

\subsubsection{Local pest dynamics}

The local pest dynamics is based on a system of two first order differential equations that represent

the ecological interactions of both pests affected by the pest management practices and natural enemies:

$$
\left\{\begin{array}{l}
\frac{d N_{1}(\mathrm{t}, \mathrm{x}, \mathrm{y})}{d t}=r_{1} N_{1}(\mathrm{t}, \mathrm{x}, \mathrm{y})\left[1-b_{11} \frac{N_{1}(\mathrm{t}, \mathrm{x}, \mathrm{y})}{k_{1}}-b_{12} \frac{N_{2}(\mathrm{t}, \mathrm{x}, \mathrm{y})}{k_{1}}-e_{1}-\delta q_{1}-\phi h(w, t)\right] \\
\frac{d N_{2}(\mathrm{t}, \mathrm{x}, \mathrm{y})}{d t}=r_{2} N_{2}(\mathrm{t}, \mathrm{x}, \mathrm{y})\left[1-b_{22} \frac{N_{2}(\mathrm{t}, \mathrm{x}, \mathrm{y})}{k_{2}}-b_{21} \frac{N_{1}(\mathrm{t}, \mathrm{x}, \mathrm{y})}{k_{2}}-e_{2}-\delta q_{2}-\phi h(w, t)\right]
\end{array}\right.
$$

With:

$$
\begin{aligned}
& \phi= \begin{cases}1, & N_{1}+N_{2} \geq E T \\
0, & \text { Otherwise }\end{cases} \\
& \delta= \begin{cases}0.8, & \text { Bt maize } \\
0, & \text { Connventional maize }\end{cases}
\end{aligned}
$$

The pest populations grow according to a classic logistical growth equation where population dynamics are influenced by: the theoretical growth rate, $\boldsymbol{r}_{i}$; the species' intrinsic carrying capacity, $\boldsymbol{k}_{i}$; intra-competition, $\boldsymbol{b}_{i i}$; inter-competition, $\boldsymbol{b}_{i j}$; mortality attributed to natural enemies, $\boldsymbol{e}_{i}$; the effectiveness of $B t$ in controlling each pest population, $\boldsymbol{q}_{i}$, and the application of insecticides, $\mathbf{w}$. The dummy variable $\boldsymbol{\phi}$ assumes the value of one if either (or both) pest reaches its economic threshold, and zero otherwise. The dummy variable $\boldsymbol{\delta}$ assumes the value of 0.8 if $B t$ maize is used, and zero otherwise. For further information on both species description and relevance to maize production see Catarino et al (2016).

\subsubsection{Spatial pest dynamics}

Two sets of partial differential equation containing the dimensionless diffusion rate, $\boldsymbol{D}_{\boldsymbol{i}}$ where $\boldsymbol{i}=\mathbf{1} ; \mathbf{2}$, were added to equation (2): 


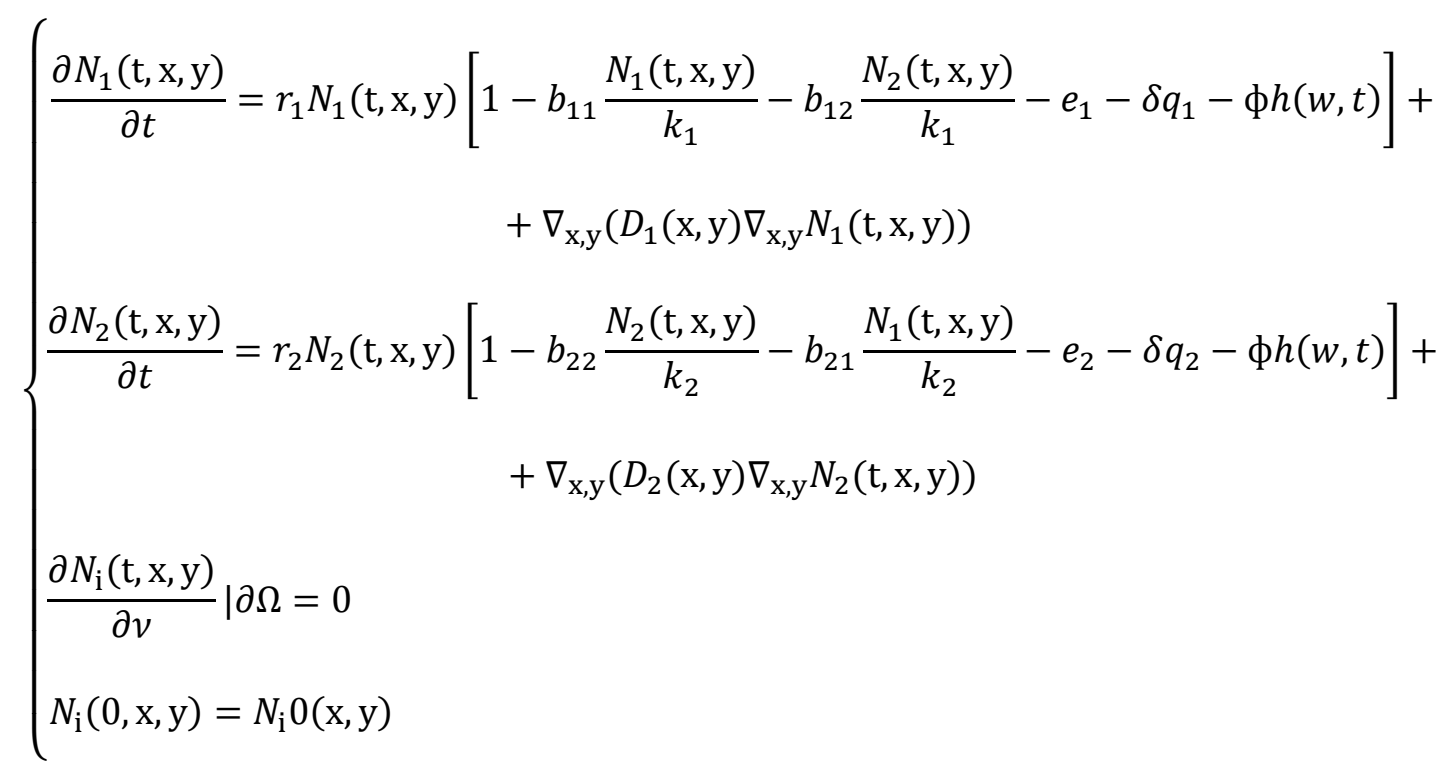

with $i \in\{1,2\},(x, y) \in \Omega, t \geq 0, \nabla_{x, y}=\frac{\partial^{2}}{\partial x^{2}}+\frac{\partial^{2}}{\partial y^{2}}, \Omega$ is the spatial domain, $v$ is the normal unit 255 vector to the frontier of $\Omega$ and $D_{\mathrm{i}}(\mathrm{x}, \mathrm{y})=\left\{\begin{array}{ll}D_{\mathrm{i}}, & \text { if favourable habitat } \\ \frac{D_{\mathrm{i}}}{1000}, & \text { otherwise }\end{array}\right.$. Per time unit $\boldsymbol{t}$, individuals move randomly, i.e. they have equal probabilities of moving in any direction (left, right, up or down). The diffusion rate for each species was derived, as in Shigesada and Kawasaki (1997), from the theoretical maximum speed obtained in wind tunnels: for the Mediterranean corn borer is $23.3 \mathrm{~cm} . \mathrm{s}^{-1}$ (Bau et al., 1999) and $135 \mathrm{~cm} . \mathrm{s}^{-1}$ for the true armyworm (Luo et al., 2002, 1999). The dimensionless diffusion rate was obtained by adjusting the spatial and temporal domain as in Gilligan (2008). It is assumed that both species can disperse within the whole domain, with the exception of hostile habitat that includes physical barriers, such as urban areas, mountain, sand, rocks and water. The boundaries between spatial units are fixed during the course of the simulation. The homogeneous Neumann boundary conditions (null derivative specified on the boundaries), were set for the spatial dimensions.

\subsubsection{Pest control methods}

Both pests are assumed to act simultaneously and the nature of the damage is species independent, but with same negative impact upon yield. Farmers have two means of suppressing these pests, by using $B t$ maize variety (pre-emptive action) and/or spraying insecticide when pest densities exceed an economic threshold (ET). The two pests have different susceptibility to the $B t$ toxin. It is assumed that

$271 N_{1}$ is highly susceptible $\left(\boldsymbol{q}_{1}=\mathbf{0 . 9 9}\right)$ and that $\boldsymbol{N}_{2}$ is weakly susceptible $\left(\boldsymbol{q}_{2}=\boldsymbol{0 . 1}\right)$ to $B t$ toxins (Catarino et al., 2016). We assumed that all $B t$ maize complied with the commonly advised $20 \%$ refuge of non- $B t$ 
maize to promote survival of susceptible pests, thus avoiding resistance building to $B t$ toxin (Tabashnik et al., 2003).

Insecticides are applied throughout the cropping season according to the ET and subject to the pest dynamics. The parameters $\boldsymbol{a}, \boldsymbol{b}, \boldsymbol{c}$ and $\boldsymbol{d}$ in Equation 4, i.e. the optimal amount of insecticides applied, referent to the best possible farmers' NPV regarding the trade-off between the reduction of the pest density and the cost of the insecticide, throughout the cropping season $(w)$, were estimated as in Catarino et al (2016). For conventional maize farmers, the optimal insecticide application takes the set of values $\{\mathbf{a}=2.877152 ; \mathbf{b}=-0.08932803 ; \mathbf{c}=0.004002907 ; \mathbf{d}=-0.00003733741\}$ and for $B t$ maize farmers: $\{\mathbf{a}=$ $1.9946108422 ; \mathbf{b}=-0.1508647313 ; \mathbf{c}=0.0060110437 ; \mathbf{d}=-0.0000316881\}$.

$$
w(t)=a+b t+c t^{2}+d t^{3}
$$

The ET was set as $25 \%$ of the economic injury level (EIL) as suggested by Pedigo et al (1986). In Equation 5a, $\boldsymbol{p}_{\boldsymbol{w}}$ is the cost of management per unit $(€ / \mathrm{ha}) ; \boldsymbol{p}_{w}$, the product market value per ton ( $€ /$ ton); $\boldsymbol{L}_{y}$, yield lost per larvae (tons/ha); and $\boldsymbol{s}$, the proportion of larvae killed (\%):

$$
E T=\frac{E I L}{4}
$$

With:

$$
E I L=\frac{p_{w}}{p_{w} L_{y} S}
$$

$$
\text { outcome are in line with published data. In 2012, the Aragon government reported an average maize }
$$
yield of approximately of around 12 tons/ha (Lopez et al., 2000). Taking into account the impact of pests, the average yield predicted by the model when farmers apply insecticides in both maize systems is relatively close to the real value, 10.9 tons/ha. In 2012 the Aragon maize (combining conventional and $B t$ maize) producers obtained an average profit of $499 € /$ ha (López, 2014), the model predicted an average profit per hectare of $670 \pm 0.04 € /$ ha for the first simulation year. The difference in the economic 
returns of the first year may be due to two factors: 1) it is assumed that all farmers act optimally which is not always the case in reality; and, 2) no other pests were taken into consideration, hence insecticide expenditures may have been higher than we have accounted for in the total costs. Similarly, in terms of insecticide expenditure, our model predictions $(48.6 \pm 0.0 € /$ ha for conventional and $11.0 \pm 2.3 € /$ ha for $B t$ farmers in Zaragoza, a region characterized by the high pest level incidence) are also in line with the results reported by (Gómez-Barbero et al (2008).

Numerous studies in Spain (Lopez et al., 2000), Canada (Fields and McNeil, 1984), the US (Willson and Eisley, 1992) and Mexico (Ramírez and Higuera, 2013) have reported on the true armyworm's destructive potential and sporadic population outbreaks with larvae marching en masse across the landscape. Attempts to analyse and predict outbreaks have been constrained by their great flying capacity and high reproduction rate of true armyworm, and its gregarious, explosive and unpredictable behaviour. Armyworms frequently disappear almost as suddenly as they appear, either burrowing into the ground to pupate or migrating to further fields in search of food. Additionally, there is a close link to temperature as this species does not have a diapause and cannot survive prolonged temperatures below freezing (Bues et al., 1986; Fields and McNeil, 1984). This has a major influence on the erratic nature of true armyworm's outbreaks and invasions. Thus, there may be an extended period of farmers not noticing the pest. In this work, the best knowledge reported in literature was used to evaluate the possible spread pattern of true armyworm in Aragon.

\section{Results and discussion}

\subsection{Modelling overview}

The model analysis focused on the economic impact of the spread of true armyworm on maize farmers' gains under three different pest management strategies (PMS) based on optimal insecticide applications (see Catarino et al (2016) for details on the methodology) and five different $B t$ maize adoption scenarios. The true armyworm's spread is influenced by the landscape and competition with the main or primary pest, Mediterranean corn borer. In general terms, the overall control success, i.e. regional or farmers' economic returns, is defined in terms of achieving the highest NPV after a given 
time span, 25 years in this case (Equation 1). Using a spatially explicit landscape model we aim to answer two specific questions: 1) What is the influence of landscape characteristics and Mediterranean corn borer competition on true armyworm's spread and the consequent economic impact; and,2) what is the influence of the regional area in which $B t$ maize is grown on true armyworm's spread and the consequent economic impact? We discuss potential policy and subsequent management strategies to address these issues. In this study, geographic information data on real landscapes were used as it was critical to access the feasibility of a spatial $B t$ maize expansion under realistic constraints.

\subsection{True armyworm spread is influenced by landscape characteristics}

When evaluating spatial distributions and the establishment of invasive species in new niches it is important to consider the area under management as well as the ecological and economic impacts associated with the management control options (Keller et al., 2007). The spatial structure, i.e. the connectivity of favourable fields for dispersion and reproduction (Jager et al., 2005), is another important factor which could have a strong influence on the dynamics and control of invasive species (Epanchin-Niell and Wilen, 2012). Here, two perspectives are considered in order to label an area as effectively invaded: 1) an agronomic perspective, i.e. when true armyworm density is above the ET per hectare, and 2) an ecological perspective, i.e. when at least one individual can be found per hectare.

From an agronomic perspective, about half of the Aragon area was invaded by true armyworm in our simulations: $47.3 \pm 8.6 \%, 47.9 \pm 6.9 \%$ and $49.7 \pm 6.7 \%$ for PMS1, PMS2 and PMS3 respectively (Table III). The model results suggest that the variance in total invaded area (TAI) could be explained by the initial introduction area (or outbreak point) of true armyworm (Fig. 3). Depending on the starting point, the total invaded maize area varied from a minimum of $92 \mathrm{~km}^{2}$ to a maximum of $298 \mathrm{~km}^{2}$ (17 and $56 \%$ of total maize area) in PMS1, and $310 \mathrm{~km}^{2}$ (58\% of total maize area) in PMS2 (Table III). Insecticide applications did not stop or meaningfully alter true armyworm's invasion. Using insecticides in both cropping systems (PMS1) reduced the TAI by only c. 3.5\%, when compared to no insecticide use in the $B t$ maize strategy (PMS3). Figs. $4 \mathrm{a}$ and $4 \mathrm{~b}$ shows the invasion patterns from two distinct initial points, illustrating how the invaded area is highly dependent on the place in which the outbreak occurs. 
This suggests that only controlling the invasive species in maize fields is not an efficient management strategy. As outlined by Catarino et al (2015), the use a specific pest control strategy, such as $B t$ maize, may cause highly complex changes in the agro ecosystems. Bt maize could create a mechanism for the spread of secondary pest species that are not susceptible to a particular $B t$ toxin. The model results suggest that after 25 years virtually the whole region would be populated by at least one true armyworm per ha, regardless of the PMS adopted (Table III). Thus, it can be expected that the growth and spread will continue until suitable habitats and resources become scarce, which may cause serious constraints to farmers. Extending the geographic range of the secondary pest brings additional potential risks. Notably, if a mutation appears to be linked to some form of partial resistance to current insecticides, it could spread quicker throughout the geographic range, with no means of immediate control.

Even though our results suggest that most suppressive effect on the pest is achieved by having every farmer spraying pesticides in their fields, further efficient control measures should be looked for at other scales, which might be calling for regional coordination. The model assumes that no communication exists between farmers (i.e. farmers are not aware of what occurs in areas neighbouring their fields). However, in reality, farmers' decision to control or not a pest is frequently grounded on the perceived threat of the pest in the vicinity of their fields and the guidance of governmental entities or commercial advisors (Larson et al., 2011). Furthermore, farmers in the same region are often influenced by similar circumstances. Therefore if an active communication system is in place, it could create a coordinated response for pest control that is effective at a landscape scale (Diekert, 2012; Larson et al., 2011). From an economic perspective, a cost effective strategy (that we deemed beyond the scope of our study) would likely require efficient collaboration by all farmers. An extension of the model could include direct and/or indirect communications between farmers as observed in real life (Larson et al., 2011) in which cooperation could arrive as an opportunity for a new maxima of this bioeconomic problem.

\subsection{The use of $B t$ maize improves farmers' economic returns while reducing chemical input}


The use of $B t$ maize can be economically advantageous at both the individual farmer level and the regional level while decreasing insecticide use by eliminating the target pest (Areal et al., 2013; Areal and Riesgo, 2015; Gómez-Barbero et al., 2008). However, recent literature suggests that the outbreak of secondary pests previously suppressed could reduce the economic advantages of $B t$ technology (Catarino et al., 2015). Our results show that after 25 years with PMS1, Bt farmers realize higher profits per hectare, $\sim 74 \%$ more, than conventional maize farmers while decreasing insecticides applications by about $68 \%$ (Table IV). The difference in insecticide expenditure per hectare after 25 years between both maize systems is relatively large, with conventional maize farmers spending an average of $€ 645$ per hectare and $B t$ farmers spending only $€ 50$. The use of insecticides by conventional farmers is a necessity. Not using insecticides (PMS3) would lower the NPV after 25 years by $~ 77 \%$. Whereas for $B t$ maize farmers, during the same period, not applying insecticides (PMS3) would have just a residual effect on the NPV, 2\% lower (Table IV).

At a regional level, when farmers apply insecticides in both $B t$ and conventional fields, the region of Aragon would obtain a total NPV of $€ 294.3 \mathrm{M}( \pm 5.5)$ after 25 years, of which $72 \%$ is attributable to $B t$ maize production. The sum of the total regional losses in maize due to true armyworm determines the benefit value of an effective control strategy. During the 25 year period the amount lost in this scenario, even when using insecticides, to both true armyworm and Mediterranean corn borer would be 15.3 M EUR ( \pm 3.4$)$, c. $5 \%$ of the total NPV, of which $69 \%$ is directly linked to true armyworm. When direct losses to pests are taken into account together with the total insecticide expenditure, approximately $€ 31 \mathrm{M}$ is lost in 25 years in Aragon (Table IV). Results at both farmer and regional level show the high efficiency of $B t$ maize usage towards the primary pest. Since we have assumed that there was no communication within farmers and insecticides were only applied in maize fields, the NPV per hectare according to the initial outbreak field was identified to infer its influence on the final maize farmers' average NPV (Table V). When the outbreak originated outside of the maize fields, the farmers' NPV was c. $2 \%$ lower. This small variation suggests that the final NPV is not dependent on the type of field in which the outbreak occurs. 

also the geographic range of secondary pests

The Aragon's regional ratio of conventional/Bt maize has a preponderant effect on the true armyworm's economic impact (Table VI). The economic and environmental (by reducing the necessity of insecticide) benefit of expanding $B t$ maize in Aragon are evident. The higher the area planted with $B t$ maize, the higher the aggregated regional profits. Intensifying the $B t$ cropping area by $50 \%$, would bring an extra $16 \%$ to Aragon's maize economic revenues. Most importantly, it would reduce insecticide expenditure by an average of $51 \%$. Interestingly, by increasing $B t$ hectarage, conventional farmers would also be c. $2 \%$ better off economically, while decreasing their insecticide expenditure by c. $55 \%$. These results suggest that as in Hutchison et al (2010), the use of $B t$ maize may provide economic benefits for farmers who plant conventional maize in nearby fields. Thus, it is possible that shrinking the area of Mediterranean corn borer action, i.e. source fields, makes the pests' general control more efficient. Conversely, if farmers ceased to grow Bt maize, the economic losses could increase by $32 \%$ of the current losses in 25 years whilst at the same time more than doubling insecticide expenditure.

Regarding the true armyworm spread process, the results suggest that the invaded area and the ratio between the two maize varieties seem to be positively related, i.e. the higher the $B t$ area, the more the true armyworm area expands over the 25 year period. Thus, although the economic benefits of using $B t$ maize at a local level appear clear, it should be noted that the introduction of GEIR maize monocropping into an agricultural landscape might lead to wider issues. The simplification of cropping systems would lead to an increase in genetic uniformity of agroecosystems with subsequent negative ecological implications, such as an increase in vulnerability to pathogens or pests (Woltz et al., 2012). Hence, research on GEIR crops must consider the wider environmental impacts in order to avoid the same problems that agriculture faces with overuse of and resistance to some pesticides.

\section{Conclusion}

The results of this research are important to the European Union agriculture sector since maize is the second most important crop in EU agriculture. The Mediterranean corn borer is one of the principal 
maize borers in Europe (Eizaguirre and Fantinou, 2012), especially in areas below the 45th parallel

430 (Eizaguirre and Fantinou, 2012), since its distribution and population levels are mainly determined by 431 its sensitivity to negative winter temperatures (Gillyboeuf et al., 1994). Yet, future climate projections 432 suggest that an overall temperature increase will bring suitable conditions for the Mediterranean corn borer to proliferate in higher latitudes (Maiorano et al., 2014). Thus, in such a scenario the expansion of $B t$ maize would bring financial benefits to famers and wider society in general by alleviating the need for using insecticides. According to our model results, the use of $B t$ maize together with insecticides (at a lower rate) yields lower crop losses and higher gross margins, in line with data reported in recent studies (Areal et al., 2013; Gómez-Barbero et al., 2008; Meissle et al., 2010). However, farmers adopting $B t$ maize need to be aware of future potential invasion of (new) pests that are not susceptible to the toxin. If the occurrence of secondary pests is not identified and dealt with at an early stage it is possible that population numbers will establish and expand beyond the ET and spread throughout an entire region. This research suggests that the establishment of a secondary pest leads to severe economic impacts even if insecticides are applied in combination with the $B t$ maize. The results also suggest that damage to crops from secondary pests can increase with the expansion of $B t$ maize if no additional measures are used, such as additional insecticide applications or the use of stacked traits. It is important to note that in addition to the economic impacts and increase in insecticide applications, the secondary pest might cause several other negative effects with possible trophic cascading effects, e.g. by having a negative influence on other species (natural enemies), or being a vector of diseases. Therefore, the situation at hand remains sensitive and is surrounded by a high level of uncertainty regarding the expected magnitude of impacts, as the latent effects of $B t$ maize expansion cannot be completely predicted. secondary pest species in an area and its detection (Solow and Costello, 2004). This is of particular importance in GEIR cropping since $B t$ maize farmers are usually less active in scouting their maize fields for the presence of pests (Wilson et al., 2005). If $B t$ maize farmers fail to rapidly identify a pest that is not susceptible to the toxin expressed by the GE maize, it will allow a window of time large 
enough for population numbers to increase and for the pest to spread throughout the region. Successful pest management programs are clearly subject to the capacity of farmers, stakeholders and agencies to recognise, detect and report new incursions (Macfadyen et al., 2018). We suggest that governments require land managers to adopt quarantine measures or carry out detection campaigns and legislative control measures. Although prevention is cost intensive, its benefits are likely to outweigh its costs, particularly for highly mobile and resource generalist species such as true armyworm. Lastly, we recommend that further modelling investigations should be done with regard to seasonal temperature constraints on insect development. Phase shifts in occurrence might be a constraint not completely covered here, that may have implications on the competition between and within two species, hence on secondary pest expansion.

\section{Acknowledgments:}

This publication was produced within the context of the "Assessing and Monitoring the Impacts of Genetically Modified Plants on Agro-ecosystems" (AMIGA) project, FP7-KBBE-2011-5-CP-CS. The AMIGA project was funded by the European Commission under the Seventh Framework Programme. We thank Carin Reisinger for her proofreading, which greatly improved the manuscript.

\section{References}

Aadland, D., Sims, C., Finnoff, D., 2014. Spatial Dynamics of Optimal Management in Bioeconomic Systems. Comput. Econ. 1-51. https://doi.org/10.1007/s10614-014-9442-y

Agency European Environment, 2010. Corine Land Cover 2006 raster data [WWW Document]. Eur. Environ. Agency. URL http://www.eea.europa.eu/data-and-maps/data/clc-2006-raster (accessed 12.1.16).

AGPME, 2012. Estudio de costes globales del cultivo del maíz en Aragón para variedades transgénicas y convencionales [WWW Document]. Estud. costes Glob. del Cultiv. del maíz en Aragón para variedades transgénicas y Conv. Asoc. Gen. Prod. Maiz España. URL http://s316151096.mialojamiento.es/index.php?option=com_content\&view=article \&id=158:estu dio-de-costes-globales-del-cultivo-del-maiz-en-aragon-para-variedades-transgenicas-yvariedades-convencionales\&catid=44: articulos $\&$ Itemid $=68$. (accessed 2.15.17). 
Albajes, R., Konstantopoulou, M., Etchepare, O., Eizaguirre, M., Fr??rot, B., Sans, A., Krokos, F., Am??line, A., Mazomenos, B., 2002. Mating disruption of the corn borer Sesamia nonagrioides (Lepidoptera: Noctuidae) using sprayable formulations of pheromone. Crop Prot. 21, 217-225. https://doi.org/10.1016/S0261-2194(01)00088-6

Alexandri, M.P., Tsitsipis, J.A., 1990. Influence of the egg parasitoid Platytelenomus busseolae [Hym.: Scelionidae] on the population of Sesamia nonagrioides [Lep.: Noctuidae] in central Greece. BioControl 35, 61-70.

Areal, F.J., Riesgo, L., 2015. Probability functions to build composite indicators: A methodology to measure environmental impacts of genetically modified crops. Ecol. Indic. 52, 498-516. https://doi.org/10.1016/j.ecolind.2015.01.008

Areal, F.J., Riesgo, L., Rodríguez-Cerezo, E., 2013. Economic and agronomic impact of commercialized GM crops: a meta-analysis. J. Agric. Sci. 151, 7-33. https://doi.org/10.1017/S0021859612000111

Bau, J., Martínez, D., Renou, M., Guerrero, A., 1999. Pheromone-triggered orientation flight of male moths can be disrupted by trifluoromethyl ketones. Chem. Senses 24, 473-480. https://doi.org/10.1093/chemse/24.5.473

Bourhis, Y., Poggi, S., Mammeri, Y., Cortesero, A.M., Le Ralec, A., Parisey, N., 2015. Perceptionbased foraging for competing resources: Assessing pest population dynamics at the landscape scale from heterogeneous resource distribution. Ecol. Modell. 312, 211-221. https://doi.org/10.1016/j.ecolmodel.2015.05.029

Bues, R., Poitout, S., Anglade, P., Robin, J.C., 1986. Cycle évolutif et hivernation de Mythimna (Syn. Pseudaletia) unipuncta Haw.(Lep. Noctuidae) dans le sud de la France. Acta oecologica. Acta oecologica. Oecologia Appl. 7, 151-166.

Butrón, A., Malvar, R.A., Velasco, P., Vales, M.I., Ordás, A., 1999. Combining Abilities for Maize Stem Antibiosis, Yield Loss, and Yield under Infestation and Non Infestation with Pink Stem Borer. Crop Sci. 39, 691-696. https://doi.org/10.2135/cropsci1999.0011183X003900020015x

Butrón, A., Revilla, P., Sandoya, G., Ordás, A., Malvar, R.A., 2009. Resistance to reduce corn borer damage in maize for bread, in Spain. Crop Prot. 28, 134-138. 
513 Catarino, R., Ceddia, G., Areal, F., Parisey, N., Park, J., 2016. Managing maize under pest species competition: Is Bt (Bacillus thuringiensis) maize the solution? Ecosphere 7.

Catarino, R., Ceddia, G., Areal, F.J., Park, J., 2015. The impact of secondary pests on Bacillus thuringiensis (Bt) crops. Plant Biotechnol. J. 13, 601-612. https://doi.org/10.1111/pbi.12363

Costamagna, A.C., Menalled, F.D., Landis, D.A., 2004. Host density influences parasitism of the

Eddelbuettel, D., 2015. Package 'RcppDE.' Cran 1-13.

Eichenseer, H., Strohbehn, R., Burks, J., 2008. Frequency and severity of western bean cutworm

Eizaguirre, M., López, C., Sans, A., Bosch, D., Albajes, R., 2009. Response of mythimna unipuncta 
540 Eizaguirre, M., Pons, P., 2003. Els enemics naturals de les plagues dels cultius de cereals a Catalunya, in: Enemics Naturals de Plagues En Diferents Cultius a Catalunya. Institució Catalana d'Estudis

Epanchin-Niell, R.S., Wilen, J.E., 2012. Optimal spatial control of biological invasions. J. Environ. Econ. Manage. 63, 260-270. https://doi.org/10.1016/j.jeem.2011.10.003

Farinos, G.P., Andreadis, S.S., de la Poza, M., Mironidis, G.K., Ortego, F., Savopoulou-Soultani, M., Castañera, P., 2011. Comparative assessment of the field-susceptibility of Sesamia nonagrioides to the Cry1 Ab toxin in areas with different adoption rates of Bt maize and in Bt-free areas. Crop Prot. 30, 902-906. https://doi.org/10.1016/j.cropro.2011.03.011

Fields, P.G., McNeil, J.N., 1984. The overwintering potential of true armyworm, Pseudaletia Unipuncta (lepidoptera: noctuidae), populations in Quebec. Can. Entomol. 116, 1647-1652. https://doi.org/DOI: 10.4039/Ent1161647-12

Figueiredo, D., Araujo, J., 1996. Mortality factors of Sesamia nonagrioides Lef.(Lepidoptera: Noctuidea) in Portugal. I. Parasitoids. Boletín Sanid. Veg. Plagas 22, 251-260.

Folcher, L., Jarry, M., Weissenberger, A., Gérault, F., Eychenne, N., Delos, M., Regnault-Roger, C., 2009. Comparative activity of agrochemical treatments on mycotoxin levels with regard to corn borers and Fusarium mycoflora in maize (Zea mays L.) fields. Crop Prot. 28, 302-308. https://doi.org/10.1016/j.cropro.2008.11.007

Gilligan, C., 2008. Sustainable agriculture and plant diseases: an epidemiological perspective. Philos. Trans. R. Soc. B Biol. Sci. 363, 741-759. https://doi.org/10.1098/rstb.2007.2181

Gillyboeuf, N., Anglade, P., Lavenseau, L., Peypelut, L., 1994. Cold hardiness and overwintering strategy of the pink maize stalk borer, Sesamia nonagrioides Lef (lepidoptera, noctuidae). Oecologia 99, 366-373. https://doi.org/10.1007/BF00627750

Gómez-Barbero, M., Berbel, J., Rodríguez-Cerezo, E., 2008. Bt corn in Spain: the performance of the EU's first GM crop. Nat. Biotechnol. 26, 384-386. https://doi.org/10.1038/nbt0408-384

González-Cabrera, J., García, M., Hernández-Crespo, P., Farinós, G.P., Ortego, F., Castañera, P., 2013. 
Resistance to bt maize in mythimna unipuncta (lepidoptera: Noctuidae) is mediated by alteration in crylab protein activation. Insect Biochem. Mol. Biol. 43, 635-643. https://doi.org/10.1016/j.ibmb.2013.04.001

González-Núñez, M., Ortego, F., Castañera, P., 2000. Susceptibility of Spanish populations of the corn borers Sesamia nonagrioides (Lepidoptera: Noctuidae) and Ostrinia nubilalis (Lepidoptera: Crambidae) to a Bacillus thuringiensis endotoxin. J. Econ. Entomol. 93, 459-463.

Guppy, C., 1967. Insect Parasites of the Armyworm, Pseudaletia unipuncta ( Lepidoptera : Noctuidae ), with Notes on Species Observed in Ontario 94-106. https://doi.org/10.4039/Ent9994-1

He, H., 2002. Introduction of Diabrotica virgifera virgifera into the Old World and its consequences: a recently acquired invasive alien pest species on Zea mays from North America. Commun. Agric. Appl. Biol. Sci. 68, 45-57.

Hellmich, R.L., Albajes, R., Bergvinson, D., Prasifka, J.R., Wang, Z.-Y., Weiss, M.J., 2008. The present and future role of insect-resistant genetically modified maize in IPM, in: Jörg Romeis, Anthony M. Shelton, George G. Kennedy (Eds.), Integration of Insect-Resistant Genetically Modified Crops within IPM Programs. Springer, pp. 119-158.

Hijmans, R.J., 2014. Geographic data analysis and modeling. R Packag. version 2, 15.

Hill, M.G., Atkins, A.W., 1982. Effects of defoliation by cosmopolitan armyworm, mythimna separata (walker) on maize yield. New Zeal. J. Agric. Res. 25, 251-254. https://doi.org/10.1080/00288233.1982.10420920

Hundsdorfer, W., Verwer, J.G., 2003. Numerical solution of time-dependent advection-diffusionreaction equations. Springer Science \& Business Media.

Hutchison, W.D., Burkness, E.C., Mitchell, P.D., Moon, R.D., Leslie, T.W., Fleischer, S.J., Abrahamson, M., Hamilton, K.L., Steffey, K.L., Gray, M.E., Hellmich, R.L., Kaster, L. V, Hunt, T.E., Wright, R.J., Pecinovsky, K., Rabaey, T.L., Flood, B.R., Raun, E.S., 2010. Areawide suppression of European corn borer with Bt maize reaps savings to non-Bt maize growers. Science 330, 222-225. https://doi.org/10.1126/science.1190242

Hyde, J., Martin, M.A., Preckel, P. V, Edwards, C.R., 1999. The economics of Bt corn: valuing 
protection from the European Corn Borer. Rev. Agric. Econ. 21, 442-454. https://doi.org/10.2307/1349890

Jager, H.I., King, A.W., Schumaker, N.H., Ashwood, T.L., Jackson, B.L., 2005. Spatial uncertainty analysis of population models. Ecol. Modell. 185, 13-27. https://doi.org/10.1016/j.ecolmodel.2004.10.016

James, C., 2014. Global status of commercialised biotech/GM crops: 2014, ISAAA Brief No. 49. International service for the acquisition of agri-biotech applications. 978-1-892456-59-1, Ithaca, NY.

Jardine, S.L., Sanchirico, J.N., 2018. Estimating the cost of invasive species control. J. Environ. Econ. Manage. 87, 242-257. https://doi.org/https://doi.org/10.1016/j.jeem.2017.07.004

Kaya, H.K., 1985. Susceptibility of Early Larval Stages of Pseudaletia unipuncta and Spodoptera exigua ( Lepidoptera: Noctuidae) to the Entomogenous Nematode Steinernema feltiae ( Rhabditida: Steinernematidae ) 62, 58-62.

Keller, R.P., Lodge, D.M., Finnoff, D.C., 2007. Risk assessment for invasive species produces net bioeconomic benefits. Proc. Natl. Acad. Sci. 104, 203-207. https://doi.org/10.1073/pnas.0605787104

Kolseth, A.-K., D’Hertefeldt, T., Emmerich, M., Forabosco, F., Marklund, S., Cheeke, T.E., Hallin, S., Weih, M., 2015. Influence of genetically modified organisms on agro-ecosystem processes. Agric. Ecosyst. Environ. 214, 96-106. https://doi.org/https://doi.org/10.1016/j.agee.2015.08.021

Kot, M., Lewis, M.A., van den Driessche, P., 1996. Dispersal data and the spread of invading organisms. Ecology 77, 2027-2042.

Larson, D.L., Phillips-Mao, L., Quiram, G., Sharpe, L., Stark, R., Sugita, S., Weiler, A., 2011. A framework for sustainable invasive species management: Environmental, social, and economic $\begin{array}{lllll}\text { objectives. } & \text { J. } & \text { Environ. } & \text { Manage. }\end{array}$ https://doi.org/http://doi.org/10.1016/j.jenvman.2010.08.025

Laub, C.A., Luna, J.M., 1992. Winter Cover Crop Suppression Practices and Natural Enemies of Armyworm (Lepidoptera: Noctuidae) in No-Till Corn. Environ. Entomol. 21, 41-49. 
Liebhold, A.M., Berec, L., Brockerhoff, E.G., Epanchin-Niell, R.S., Hastings, A., Herms, D.A., Kean, J.M., McCullough, D.G., Suckling, D.M., Tobin, P.C., Yamanaka, T., 2016. Eradication of Invading Insect Populations: From Concepts to Applications. Annu. Rev. Entomol. 61, 335-352. https://doi.org/10.1146/annurev-ento-010715-023809

Lindroth, A.E., Hunt, T.E., Skoda, S.R., Culy, M.D., Lee, D., 2012. Population Genetics of the Western Bean Cutworm ( Lepidoptera: Noctuidae ) Across the United States Population Genetics of the Western Bean Cutworm ( Lepidoptera : Noctuidae ) Across the United States. Ann. Entomol. Soc. Am. 105, 685-692.

López, C., Madeira, F., Pons, X., Eizaguirre, M., 2008. Desarrollo larvario y número de estadios larvarios de Pseudaletia unipuncta alimentada con dos variedades de maíz y dos dietas semisintéticas. Boletín Sanid. Veg. Plagas 34, 267-274.

Lopez, C., Sans, A., Eizaguirre, M., 2000. Vuelos de la defoliadora de maíz , pastos y céspedes , Mythimna ( Pseudaletia ) unipuncta ( Haworth ) en la zona de Lleida. Boletín Sanid. Veg. Plagas $26,255-259$.

López, M.G., 2014. Resultados de la red de ensayos de variedades de maíz y girasol en Aragón. Campaña 2013, Gobierno de Aragón: Técnicas del Departamento de Agricultura, Ganadería y Medio Ambiente del gobierno de Aragón (Dirección General de Alimentación y Fomento Agroalimentario, Servicio de Recursos Agrícolas).

Lövei, G.L., Andow, D. a, Arpaia, S., 2009. Transgenic insecticidal crops and natural enemies: a detailed review of laboratory studies. Environ. Entomol. 38, 293-306. https://doi.org/10.1603/022.038.0201

Luo, L., Jiang, X., Li, K., Hu, Y., 1999. Influences of flight on reproduction and longevity of the oriental armyworm, Mythimna separata (Walker). Kun chong xue bao. Acta Entomol. Sin. 42, 150-158.

Luo, L., Johnson, S., Hammond, A., Lopez, J., Geaghan, J., Beerwinkle, K., Westbrook, J., 2002. Determination and Consideration of Flight Potential in a Laboratory Population of True Armyworm (Lepidoptera: Noctuidae). Environ. Entomol. 31, 1-9. https://doi.org/10.1603/0046225X-31.1.1 
Macfadyen, S., McDonald, G., Hill, M.P., 2018. From species distributions to climate change adaptation: Knowledge gaps in managing invertebrate pests in broad-acre grain crops. Agric. Ecosyst. Environ. 253, 208-219. https://doi.org/https://doi.org/10.1016/j.agee.2016.08.029

MAGRAMA, 2018. Anuario de Estadística 2017, in: Ministerio de Agricultura y Pesca, Alimentación y Medio Ambiente - Estadisticas Agrarias. Capitulo 17: Indicadores Economicos. Madrid, p. 1063.

MAGRAMA, 2013. Anuario de Estadística 2012, in: Anuario de Estadistica Ministerio de Agricultura Alimentación y Medio Ambiente. Capitulo 13: Superficies y Producciones De Cultivos. Madrid, p. 1137.

Maiorano, A., Cerrani, I., Fumagalli, D., Donatelli, M., 2014. New biological model to manage the impact of climate warming on maize corn borers. Agron. Sustain. Dev. 34, 609-621. https://doi.org/10.1007/s13593-013-0185-2

Malvar, R.A., Butrón, A., Alvarez, A., Ordás, B., Soengas, P., Revilla, P., Ordás, A., 2004. Evaluation of the European Union Maize Landrace Core Collection for Resistance to Sesamia nonagrioides (Lepidoptera: Noctuidae) and Ostrinia nubilalis (Lepidoptera: Crambidae). J. Econ. Entomol. 97, 628-634. https://doi.org/10.1603/0022-0493-97.2.628

Meissle, M., Lang, A., 2005. Comparing methods to evaluate the effects of Bt maize and insecticide on spider assemblages. Agric. Ecosyst. Environ. 107, 359-370. https://doi.org/https://doi.org/10.1016/j.agee.2004.12.007

Meissle, M., Mouron, P., Musa, T., Bigler, F., Pons, X., Vasileiadis, V.P., Otto, S., Antichi, D., Kiss, J., Pálinkás, Z., Dorner, Z., Van Der Weide, R., Groten, J., Czembor, E., Adamczyk, J., Thibord, J.B.B., Melander, B., Nielsen, G.C., Poulsen, R.T., Zimmermann, O., Verschwele, A., Oldenburg, E., 2010. Pests, pesticide use and alternative options in European maize production: Current status and future prospects. J. Appl. Entomol. 134, 357-375. https://doi.org/10.1111/j.14390418.2009.01491.x

Menalled, F.D., Marino, P.C., Gage, S.H., Landis, D.A., 1999. Does agricultural landscape structure affect parasitism and parasitoid diversity? Ecol. Appl. 9, 634-641. https://doi.org/10.1890/1051- 


\section{1(1999)009[0634:DALSAP]2.0.CO;2}

Monetti, L., Malvar, R.A., Ordas, A., Cordero-Rivera, A., 2003. Parasitoids incidence and diversity on maize stem borers Sesamia nonagrioides Lefèbvre and Ostrinia nubilalis Hübner in NW Spain. Maydica 48, 133-139.

Park, J., McFarlane, I., Phipps, R., Ceddia, G., 2011. The impact of the EU regulatory constraint of transgenic crops on farm income. N. Biotechnol. 28, 396-406. https://doi.org/10.1016/j.nbt.2011.01.005

Pedigo, L.P., Hutchins, S.H., Higley, L.G., 1986. Economic injury levels in theory and practice. Annu. Rev. Entomol. 31, 341-368.

Pérez-Hedo, M., López, C., Albajes, R., Eizaguirre, M., 2012. Low susceptibility of non-target Lepidopteran maize pests to the Bt protein Cry1Ab. Bull. Entomol. Res. 810, 1-7. https://doi.org/10.1017/S0007485312000351

Pérez-Hedo, M., Reiter, D., López, C., Eizaguirre, M., Carmen, L., Eizaguirre, M., 2013. Processing of the maize Bt toxin in the gut of Mythimna unipuncta caterpillars. Entomol. Exp. Appl. 148, 5664. https://doi.org/10.1111/eea.12074

Pimentel, D., McNair, S., Janecka, J., Wightman, J., Simmonds, C., O’Connell, C., Wong, E., Russel, L., Zern, J., Aquino, T., Tsomondo, T., 2001. Economic and environmental threats of alien plant, animal, and microbe invasions. Agric. Ecosyst. Environ. 84, 1-20. https://doi.org/10.1016/S01678809(00)00178-X

R Core Team, 2014. R: A Language and Environment for Statistical Computing (Version 3.1.1). R Found. Stat. Comput. Vienna, Austria. https://doi.org/10.1007/978-3-540-74686-7

Ramírez, J., Higuera, V., 2013. Modelación espacial del gusano soldado (Mythimna unipuncta) en el cultivar de maíz, en tres municipios del estado de México, en el 2008. Boletín del Mus. Entomol. la Univ. del Val. 13, 1-15.

Shigesada, N., Kawasaki, K., 1997. Biological invasions: theory and practice. Oxford University Press, UK.

Simon Wood, 2016. Package 'mgcv.' CRAN 1-244. 
Soetaert, K., Petzoldt, T., Setzer, R.W., 2015. Package 'deSolve.’ Cran 141.

Solow, A.R., Costello, C.J., 2004. Estimating the rate of species introductions from the discovery record. Ecology 85, 1822-1825. https://doi.org/10.1890/03-3102

Stephens, E.J., Losey, J.E., Allee, L.L., DiTommaso, A., Bodner, C., Breyre, A., 2012. The impact of Cry3Bb Bt-maize on two guilds of beneficial beetles. Agric. Ecosyst. Environ. 156, 72-81. https://doi.org/10.1016/j.agee.2012.05.002

Tabashnik, B.E., Carrière, Y., Dennehy, T.J., Morin, S., Sisterson, M.S., Roush, R.T., Shelton, A.M., Zhao, J.-Z., 2003. Insect resistance to transgenic Bt crops: lessons from the laboratory and field. J. Econ. Entomol. 96, 1031-1038.

Tilman, D., 1999. Global environmental impacts of agricultural expansion: the need for sustainable and efficient practices. Proc. Natl. Acad. Sci. U. S. A. 96, 5995-6000. https://doi.org/10.1073/pnas.96.11.5995

Vasileiadis, V.P., Sattin, M., Otto, S., Veres, A., Pálinkás, Z., Ban, R., Pons, X., Kudsk, P., van der Weide, R., Czembor, E., Moonen, A.C., Kiss, J., 2011. Crop protection in European maize-based cropping systems: Current practices and recommendations for innovative Integrated Pest Management. Agric. Syst. 104, 533-540. https://doi.org/10.1016/j.agsy.2011.04.002

Velasco, P., Revilla, P., Cartea, M.E., Ordás, A., Malvar, R.A., 2004. Resistance of Early Maturing Sweet Corn Varieties to Damage Caused by Sesamia nonagrioides (Lepidoptera: Noctuidae). J. Econ. Entomol. 97, 1432-1437. https://doi.org/10.1603/0022-0493-97.4.1432

Willson, H.R., Eisley, J.B., 1992. Effects of Tillage and Prior Crop on the Incidence of Five Key Pests on Ohio Corn. J. Econ. Entomol. 85, 853-859.

Wilson, T.A., Rice, M.E., Tollefson, J.J., Pilcher, C.D., 2005. Transgenic Corn for Control of the European Corn Borer and Corn Rootworms: a Survey of Midwestern Farmers' Practices and Perceptions. J. Econ. Entomol. 98, 237-247.

Woltz, J.M., Isaacs, R., Landis, D.A., 2012. Landscape structure and habitat management differentially influence insect natural enemies in an agricultural landscape. Agric. Ecosyst. Environ. 152, 4049. https://doi.org/https://doi.org/10.1016/j.agee.2012.02.008 
Code availability. The computer code used for this study is available from the corresponding

730 author upon request.

Data availability. The datasets analysed during the study are available from the corresponding

732 author upon request.

733

734 


\section{Figures}

Primary pest, Mediterranean corn borer (MCB), initial population

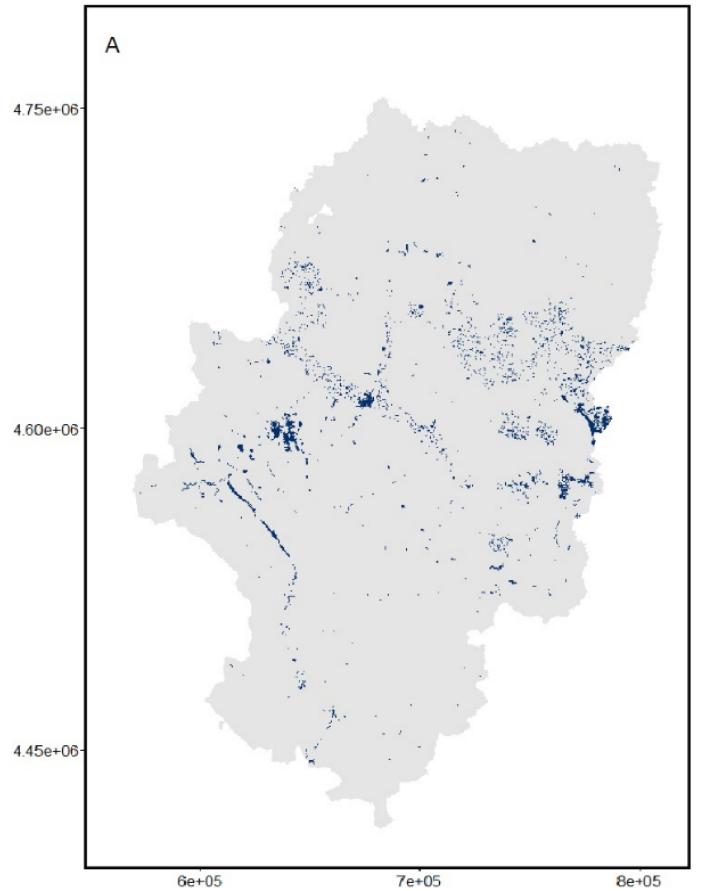

Secondary pest, true armyworm (TAW), initial population closer up view
736

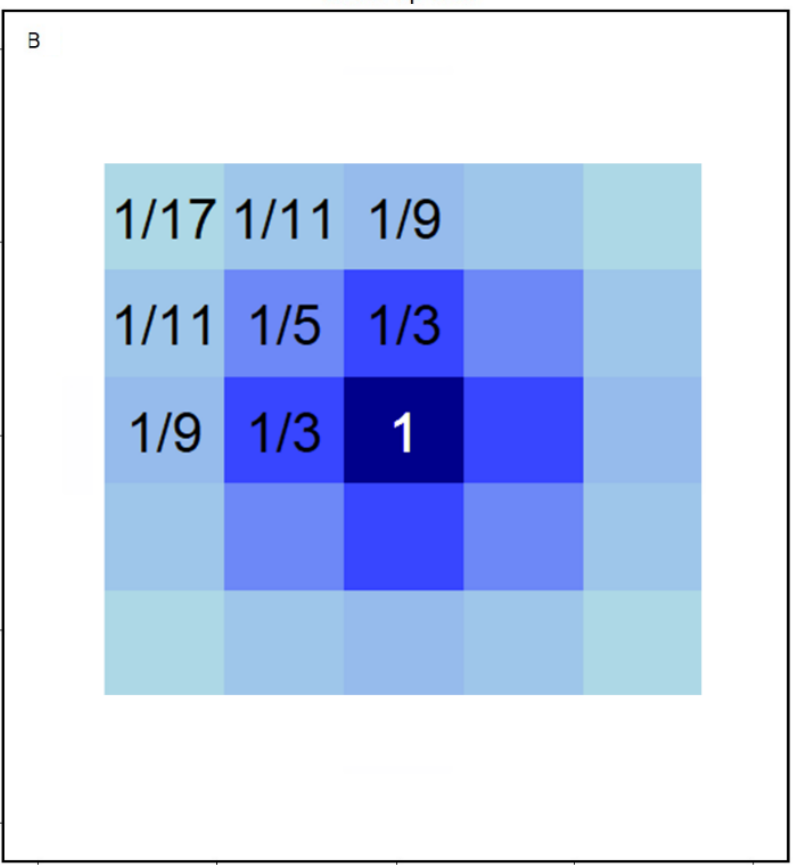

Fig. 1. Initial population of both pests, Mediterranean corn borer (MCB) and true armyworm (TAW). Fig. a) shows the initial population of MCB. It is assumed that $\mathrm{MCB}$ is present in all fields favourable to reproduction at a density equivalent to $10 \%$ of its carrying capacity on maize $\left(1.125 \times 10^{6}\right.$ individuals per cell $=4.5 \times 10^{4}$ individuals per hectare $=0.5$ individuals per maize plant). Fig. b) shows the initial population of secondary pest, true army worm (TAW), close up in the form of a Cauchy kernel, evidencing the respective proportion of individuals in relation to the population density at the centre. TAW initial population density has also a density equivalent to $10 \%$ of its carrying capacity on maize $\left(2.25 \times 10^{6}\right.$ individuals per cell $=9 \times 10^{4}$ individuals per hectare $=1$ individuals per maize plant $)$. Each cell represents 25 hectares. 

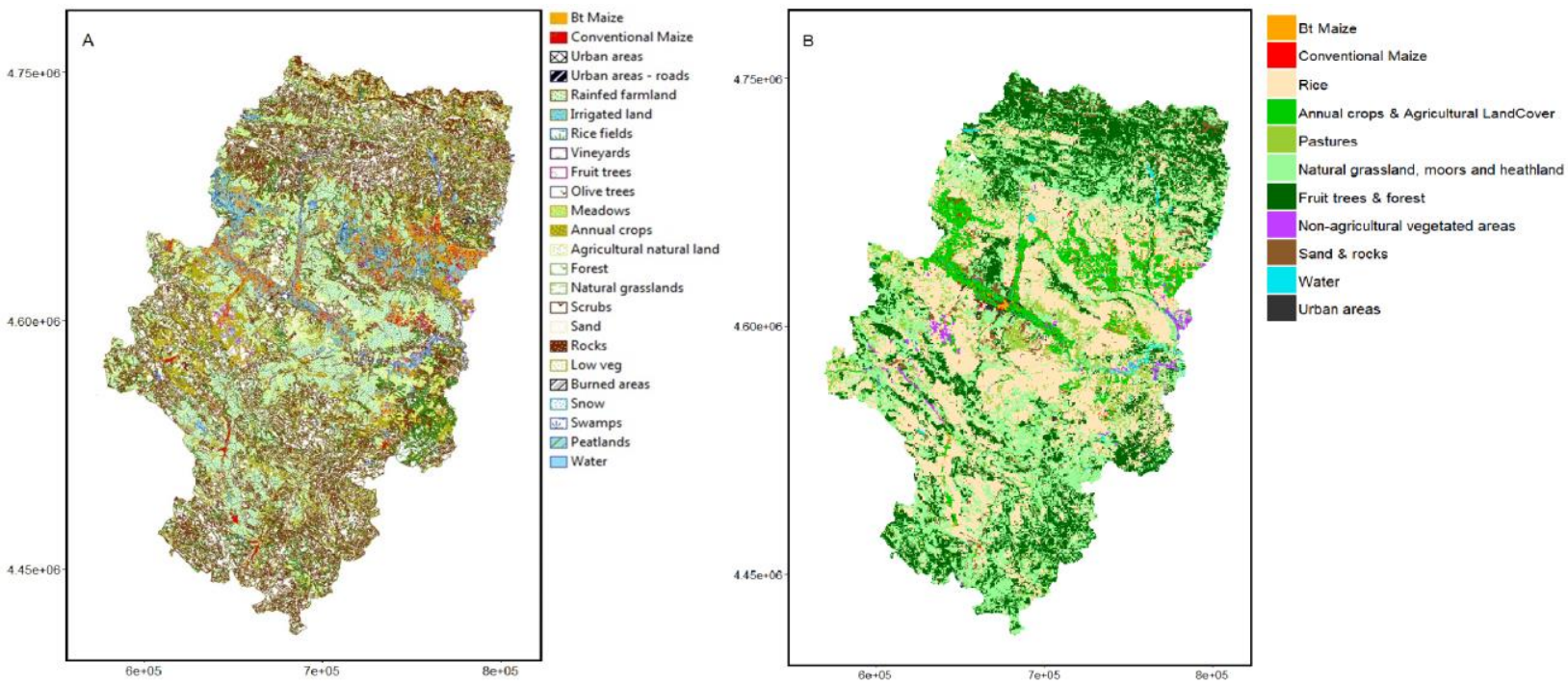

749 Fig. 2. Aragon land use maps. a) CORINE geographic land use map encompassing the main land cover categories, represented explicitly with a grid derived from an ASCII raster adapted from the CORINE 2006 Land Cover. The resolution of the data is $100 \times 100 \mathrm{~m}$. b) The original landscape aggregated for the relevant land cover types with a spatial resolution of $500 \times 500 \mathrm{~m}$, i.e. 25 ha. 

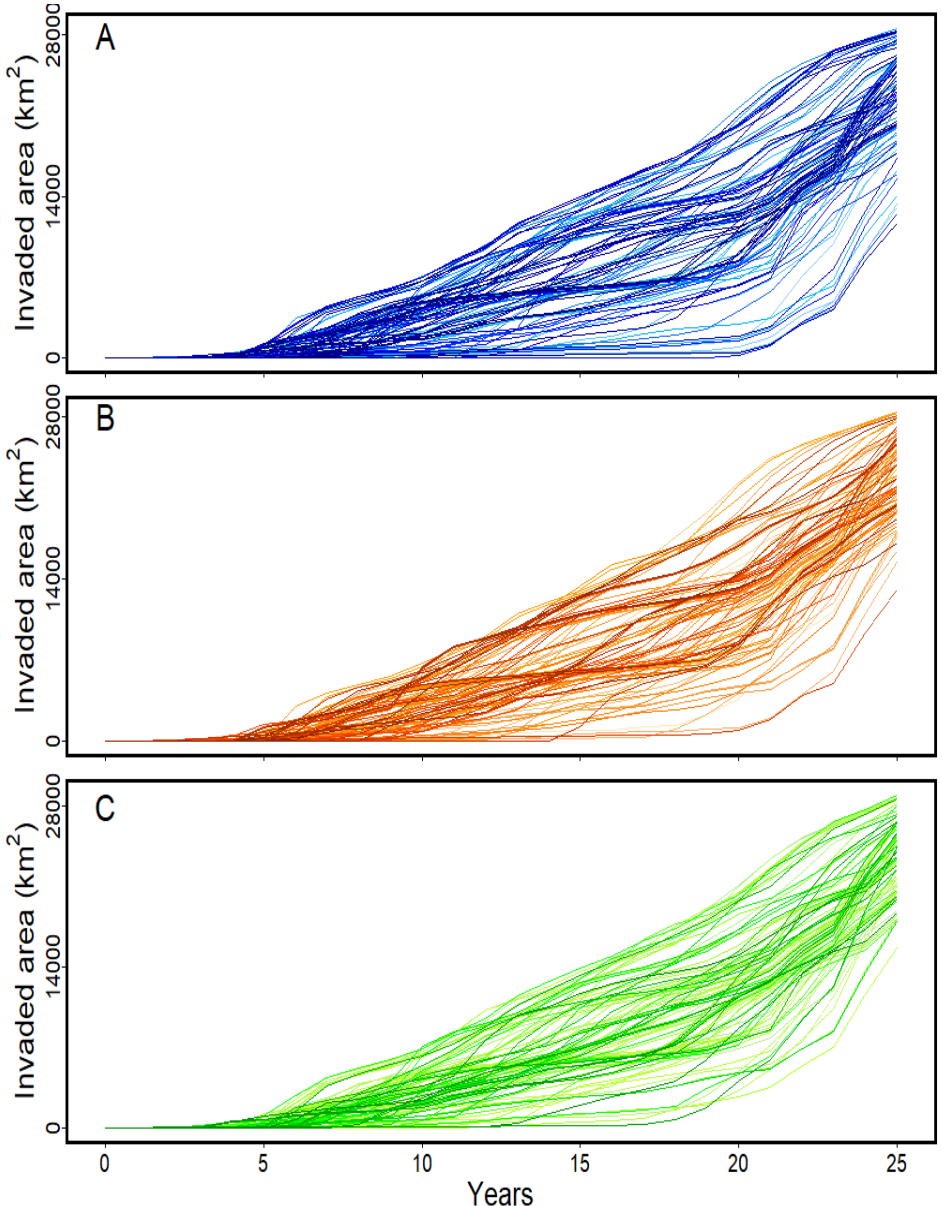

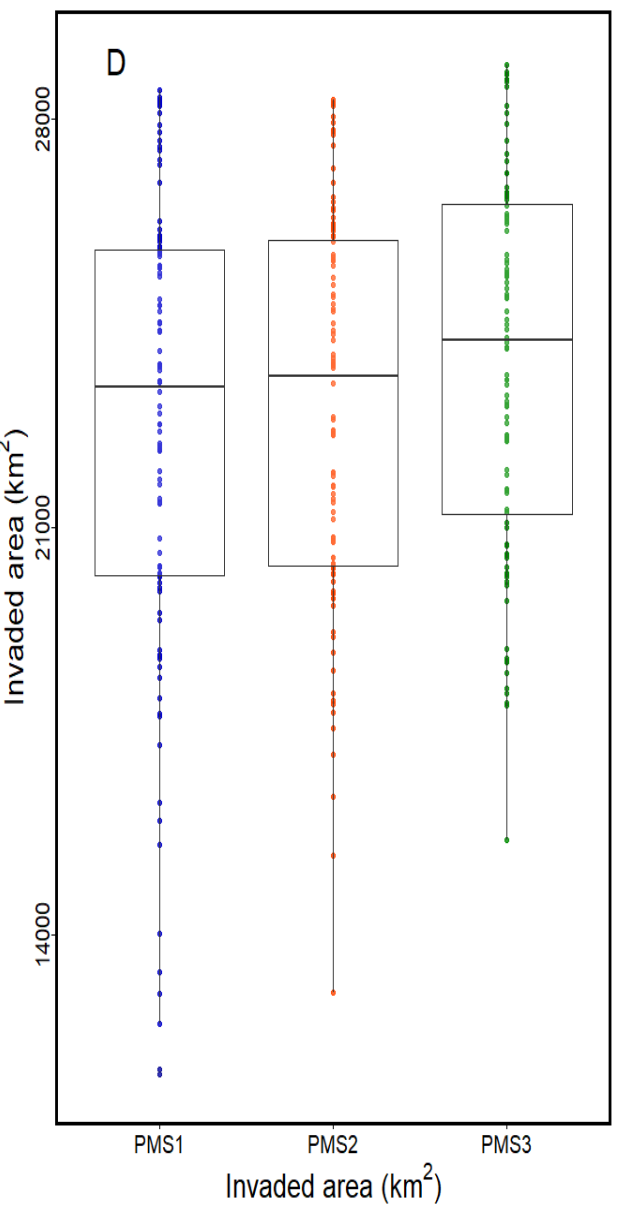

Fig. 3. Total area invaded per year throughout the 25 years when TAW surpassed the economic threshold (ET) level for the pest management strategies (PMS): insecticides are used in both $B t$ and conventional maize (A, PMS1); insecticides are used only in conventional maize (B, PMS2); insecticides are not used in neither Bt nor conventional maize (C, PMS3). Each line, in figs. A, B and $\mathrm{C}$, represents one model simulation. Depending on the starting point, the total invaded maize area after 25 years ranges from a minimum of 11615,13022 and $15636 \mathrm{~km} 2$ to a maximum of 28506, 28332 and $28939 \mathrm{~km} 2$ (51.4\%, 51.1\% and 52.2\% of the total Aragon area) on PMS1, PMS2 and PM3 respectively. The boxplots on D show the invaded area at the end of the 25 years period for the three PMSs. 

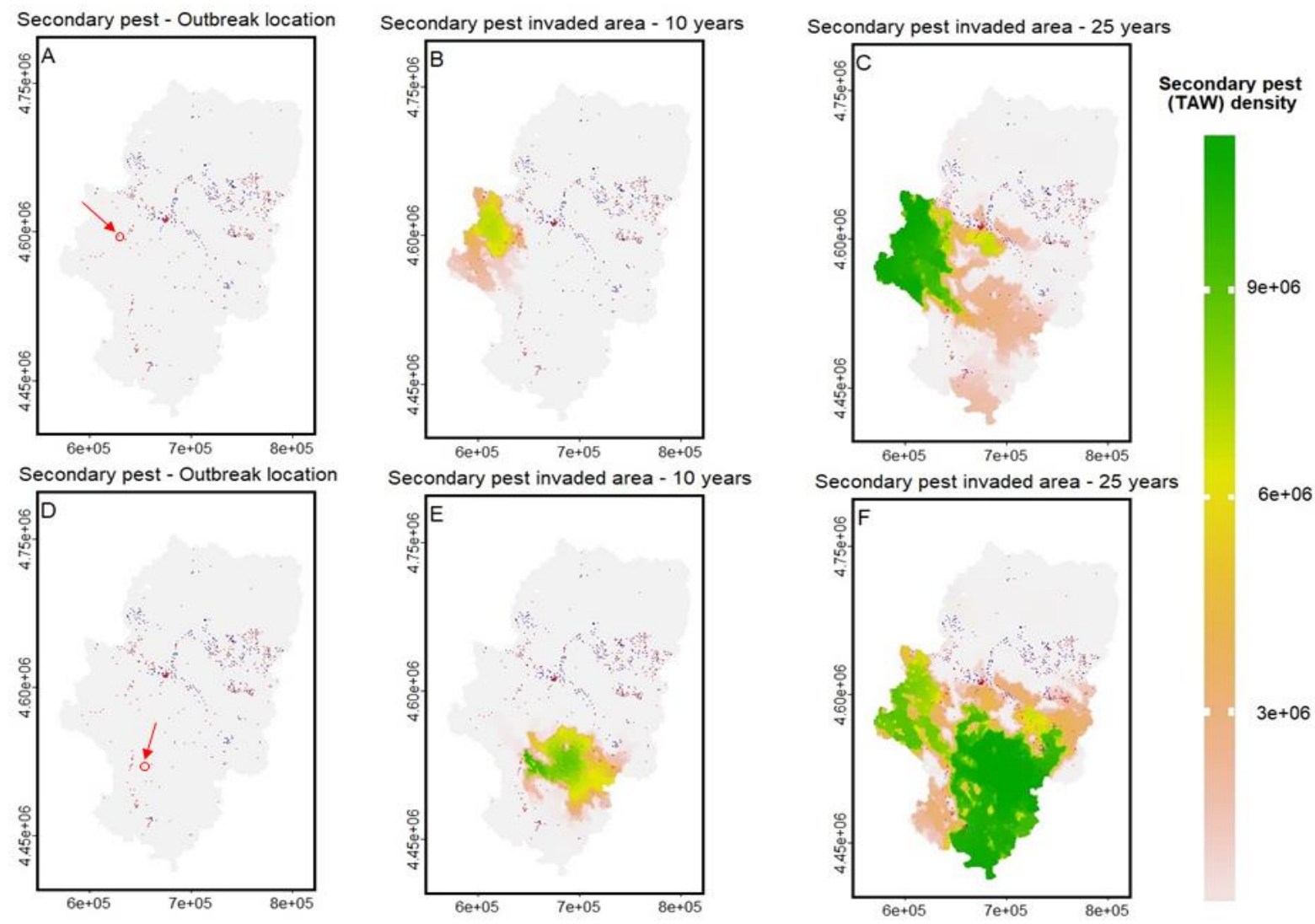

Fig. 4. Two examples of the secondary pest, true armyworm (TAW), invasion process over 25 years when insecticides are used in both $B t$ and conventional maize from two randomized simulations. Images A) and D) show the initial outbreak area, occurring in west and south west of Aragon (highlighted with red circle and arrow), respectively; B) and E) show the invasion area after 10 years; and C) and F) show the final spread accrued from these two simulations. The red cells represent $B t$ maize fields, while blue cells represent conventional maize. Values are given per cell. Each cell represents 25 hectares with $9.0 \times 10^{4}$ maize plants each. 
Table I. Aragon aggregated land use and habitat quality for both pests, Mediterranean corn borer (MCB)

779 and true armyworm (TAW). The landscape is categorised into: i) areas of favourable habitat, i.e. where

780 the species can reproduce, colonize and disperse; and ii) hostile habitat, where reproduction and

781 dispersion are impeded.

\begin{tabular}{|c|c|c|c|c|}
\hline \multirow{2}{*}{ Fields } & \multirow{2}{*}{ Area $\left(\mathrm{Km}^{2}\right)$} & \multirow{2}{*}{ Ratio (\%) } & \multicolumn{2}{|c|}{ Habitat } \\
\hline & & & MCB & TAW \\
\hline Bt Maize & 320 & $0,7 \%$ & \multicolumn{2}{|c|}{ Favourable } \\
\hline Conventional Maize & 214 & $0,4 \%$ & \multicolumn{2}{|c|}{ Favourable } \\
\hline Farmland & 8641 & $18,1 \%$ & \multicolumn{2}{|c|}{ Hostile } \\
\hline Rice & 421 & $0,9 \%$ & \multicolumn{2}{|c|}{ Favourable } \\
\hline Vineyards, fruit trees \& forest & 6397 & $13,4 \%$ & \multicolumn{2}{|c|}{ Hostile } \\
\hline Pastures & 2958 & $6,2 \%$ & Hostile & Favourable \\
\hline Natural grassland & 11850 & $24,8 \%$ & Hostile & Favourable \\
\hline Urban areas & 225 & $0,5 \%$ & \multicolumn{2}{|c|}{ Hostile } \\
\hline Non-agricultural vegetated areas & 15568 & $32,6 \%$ & \multicolumn{2}{|c|}{ Hostile } \\
\hline Mountain, sand, rocks, etc. & 859 & $1,8 \%$ & \multicolumn{2}{|c|}{ Hostile } \\
\hline Water & 280 & $0,6 \%$ & \multicolumn{2}{|c|}{ Hostile } \\
\hline Total & 47732 & 100 & & \\
\hline
\end{tabular}


Table II. Economic and biologic parameters used in the bio-economic model and respective sources.

\begin{tabular}{|c|c|c|c|c|}
\hline & & Value & Units & Source \\
\hline \multirow{11}{*}{ 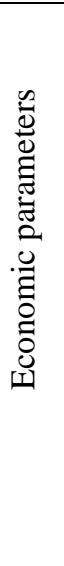 } & Plant density per hectare & 90000 & Plants/ha & (AGPME, 2012) \\
\hline & Potential conventional maize yield $\left(\mathrm{Y}_{\mathrm{c}}\right)$ & 11.30 & T/ha & (AGPME, 2012) \\
\hline & Potential $B t$ maize yield $\left(\mathrm{Y}_{B t}\right)$ & 11.80 & $\mathrm{~T} / \mathrm{ha}$ & (AGPME, 2012) \\
\hline & Price maize $(\mathrm{p})$ & 212.3 & $€ / \mathrm{T}$ & (MAGRAMA, 2018) \\
\hline & Conventional seed price $\left(\mathrm{S}_{\mathrm{c}}\right)$ & 253.80 & $€ /$ ha & (AGPME, 2012) \\
\hline & $B t$ seed price $\left(\mathrm{S}_{B t}\right)$ & 284.40 & $€ /$ ha & (AGPME, 2012) \\
\hline & Fixed costs $\left(u_{c}\right)$ & 1797.88 & $€ /$ ha & (AGPME, 2012) \\
\hline & Fixed costs $\left(u_{B t}\right)$ & 1815.88 & $€ /$ ha & (AGPME, 2012) \\
\hline & Insecticide cost per application ( $w$ ) & 18 & $€ / \mathrm{ha} / \mathrm{app}$ & (AGPME, 2012) \\
\hline & Discount rate $(\delta)$ & 0.05 & & Assumption \\
\hline & & $\mathrm{N}_{1}(\mathrm{MCB})$ & $\mathrm{N}_{2}(\mathrm{TAW})$ & \\
\hline \multirow{13}{*}{ 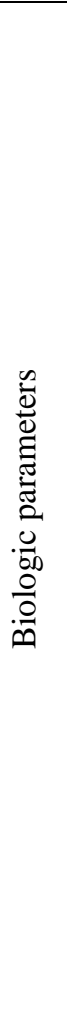 } & Growth rate $\left(\mathrm{r}_{\mathrm{i}}\right)$ & 2.02 & 3.13 & (Catarino et al., 2016) \\
\hline & Diffusion rate $\left(D_{i}\right)$ & $4.659 \times 10^{-6}$ & $9.538 \times 10^{-3}$ & See spatial pest dynamics \\
\hline & Intraspecific competition $\left(b_{i i}\right)$ & 1 & 1 & (Catarino et al., 2016) \\
\hline & Interspecific competition $\left(b_{\mathrm{ij}}\right)$ & 0.10 & 0.90 & (Catarino et al., 2016) \\
\hline & & & & MCB: (Hellmich et al., 2008) \\
\hline & Susceptibility to $B t$ toxin $\left(\mathrm{q}_{\mathrm{i}}\right)$ & 0.99 & 0.20 & $\begin{array}{l}\text { TAW: (González-Cabrera et al., } \\
\text { 2013) }\end{array}$ \\
\hline & Susceptibility to insecticide (s) & 0.80 & 0.80 & $\begin{array}{l}\text { (Folcher et al., 2009; Hyde et al., } \\
\text { 1999) }\end{array}$ \\
\hline & Minimum natural enemies impact & 0.1 & 0.1 & (Catarino et al., 2016) \\
\hline & & & & $\begin{array}{l}\text { MCB: (Alexandri and Tsitsipis, } \\
\text { 1990; Figueiredo and Araujo, } \\
\text { 1996; Monetti et al., 2003) }\end{array}$ \\
\hline & Maximum natural enemies impact & 0.65 & 0.90 & $\begin{array}{l}\text { TAW: (Costamagna et al., 2004; } \\
\text { Guppy, 1967; Kaya, 1985; Laub } \\
\text { and Luna, 1992; Malvar et al., } \\
\text { 2004) }\end{array}$ \\
\hline & Maximum larvae per plant & 5 & 10 & $\begin{array}{l}\text { (Butrón et al., 2009, 1999; Malvar } \\
\text { et al., 2004; Velasco et al., 2004) }\end{array}$ \\
\hline & Initial population (larvae per plant) & 5 & 5 & (Catarino et al., 2016) \\
\hline & Damage per larvae (I) & 0.06 & 0.06 & $\begin{array}{l}\text { (Butrón et al., 2009, 1999; Malvar } \\
\text { et al., 2004; Velasco et al., 2004) }\end{array}$ \\
\hline
\end{tabular}


Table III. True armyworm (TAW) invasion simulation results (scenario 1) after 25 years. Except when mentioned, the results refer to the case in which TAW surpasses the economic threshold (ET) in maize fields. It is showed detailed information on the predicted total area of invasion (TAI) by TAW and the density of individuals per plant for the three pest management regimes (PMR): PMS 1, insecticides are applied in both $B t$ and conventional maize; PMS 2, insecticides are only applied in conventional maize, and; PMS 3: no insecticides are applied.

\begin{tabular}{|c|c|c|c|c|}
\hline & units & Mean & Min & Max \\
\hline \multicolumn{5}{|l|}{ PMS 1} \\
\hline Aragon invasion area $\left(>1\right.$ larvae ha $\left.{ }^{-1}\right)$ & $\mathrm{km}^{2}$ & $47043 \pm 337$ & 46275 & 47527 \\
\hline Aragon invasion area & $\mathrm{km}^{2}$ & $22685 \pm 4130$ & 11632 & 28515 \\
\hline Maize invaded area & $\mathrm{km}^{2}$ & $200 \pm 57$ & 92 & 298 \\
\hline Conv maize invaded area & $\mathrm{km}^{2}$ & $76 \pm 26$ & 37 & 123 \\
\hline$B t$ maize invaded area & $\mathrm{km}^{2}$ & $124 \pm 35$ & 55 & 189 \\
\hline Total TAW average density & Insect/plant & $0.5 \pm 0.26$ & 0.08 & 1.21 \\
\hline Conventional field TAW density & Insect/plant & $0.44 \pm 0.26$ & 0.08 & 1.17 \\
\hline$B t$ fields TAW average density & Insect/plant & $0.55 \pm 0.27$ & 0.07 & 1.23 \\
\hline \multicolumn{5}{|l|}{ PMS 2} \\
\hline Aragon invasion area $\left(>1\right.$ larvae ha $\left.^{-1}\right)$ & $\mathrm{km}^{2}$ & $47080 \pm 330$ & 46343 & 47567 \\
\hline Aragon invasion area & $\mathrm{km}^{2}$ & $23012 \pm 3330$ & 13042 & 28340 \\
\hline Maize invaded area & $\mathrm{km}^{2}$ & $213 \pm 53$ & 99 & 310 \\
\hline Conv maize invaded area & $\mathrm{km}^{2}$ & $81 \pm 25$ & 38 & 130 \\
\hline$B t$ maize invaded area & $\mathrm{km}^{2}$ & $132 \pm 31$ & 60 & 192 \\
\hline Total average TAW density per plant & Insect/plant & $0.61 \pm 0.27$ & 0.09 & 1.3 \\
\hline Conv average TAW density per plant & Insect/plant & $0.53 \pm 0.27$ & 0.1 & 1.22 \\
\hline$B t$ average TAW density per plant & Insect/plant & $0.67 \pm 0.28$ & 0.09 & 1.35 \\
\hline \multicolumn{5}{|l|}{ PMS 3} \\
\hline Aragon invasion area $\left(>1\right.$ larvae $\left.\mathrm{ha}^{-1}\right)$ & $\mathrm{km}^{2}$ & $47233 \pm 260$ & 46712 & 47620 \\
\hline Aragon invasion area & $\mathrm{km}^{2}$ & $23867 \pm 3221$ & 15658 & 28950 \\
\hline Maize invaded area & $\mathrm{km}^{2}$ & $218 \pm 53$ & 128 & 317 \\
\hline Conv maize invaded area & $\mathrm{km}^{2}$ & $84 \pm 25$ & 41 & 135 \\
\hline$B t$ maize invaded area & $\mathrm{km}^{2}$ & $134 \pm 32$ & 80 & 194 \\
\hline Total average TAW density per plant & Insect/plant & $0.63 \pm 0.27$ & 0.13 & 1.32 \\
\hline Conv average TAW density per plant & Insect/plant & $0.56 \pm 0.27$ & 0.14 & 1.23 \\
\hline$B t$ average TAW density per plant & Insect/plant & $0.68 \pm 0.28$ & 0.13 & 1.38 \\
\hline
\end{tabular}


Table IV. The economic implications of predicated invasions, after 25 years, at regional and field level

797 for conventional and $B t$ maize for each of the pest management strategies (PMS). The regional economic

798 losses to pest are based on the regional optimal profit (i.e. zero losses to pests) of $€ 122.4 \mathrm{M}$ for

799 conventional maize farmers and $€ 221.6 \mathrm{M}$ for $B t$ maize farmers. Field losses to pests were determined

800 by averaging the former values for the total hectarage.

801

\begin{tabular}{|c|c|c|c|c|c|}
\hline & \multicolumn{5}{|c|}{ PMS 1} \\
\hline & Units & \multicolumn{2}{|c|}{ Conv } & \multicolumn{2}{|r|}{$B t$} \\
\hline NPV (regional level) & Million $€$ & \multicolumn{2}{|c|}{$81.6 \pm 2.3$} & \multicolumn{2}{|c|}{$212.7 \pm 3.2$} \\
\hline NPV (field level) & $€ . h a^{-1}$ & \multicolumn{2}{|c|}{$3817.2 \pm 106.3$} & \multicolumn{2}{|c|}{$6651.7 \pm 101.6$} \\
\hline Insecticide cost (regional level) & Million $€$ & \multicolumn{2}{|c|}{$13.8 \pm 3.1$} & \multicolumn{2}{|c|}{$1.7 \pm 0.4$} \\
\hline Insecticide cost (field level) & $€ . \mathrm{ha}^{-1}$ & \multicolumn{2}{|c|}{$643.68 \pm 143.76$} & \multicolumn{2}{|c|}{$49.45 \pm 12.2$} \\
\hline \multirow[t]{2}{*}{ Insecticide applications } & app.ha ${ }^{-1} \cdot$ year $^{-1}$ & \multicolumn{2}{|c|}{$2.51 \pm 0.3$} & \multicolumn{2}{|c|}{$0.81 \pm 0.16$} \\
\hline & & MCB & TAW & MCB & TAW \\
\hline Pest loss (regional level) & Million $€$ & $4.2 \pm 2.4$ & $3.2 \pm 1.9$ & $0.6 \pm 0.1$ & $7.3 \pm 3.6$ \\
\hline \multirow[t]{3}{*}{ Pest loss (field level) } & $€ . h^{-1}$ & $196.4 \pm 110.6$ & $150.7 \pm 88$ & $17.2 \pm 2.7$ & $227.7 \pm 111.5$ \\
\hline & \multicolumn{5}{|c|}{ PMS 2} \\
\hline & Units & \multicolumn{2}{|c|}{ Conv } & \multicolumn{2}{|r|}{$B t$} \\
\hline NPV (regional level) & Million $€$ & \multicolumn{2}{|c|}{$81.3 \pm 2.1$} & \multicolumn{2}{|c|}{$213.7 \pm 3$} \\
\hline NPV (field level) & $€ . h a^{-1}$ & \multicolumn{2}{|c|}{$3804.4 \pm 98.8$} & \multicolumn{2}{|c|}{$6683.1 \pm 94.5$} \\
\hline Insecticide cost (regional level) & Million $€$ & \multicolumn{2}{|c|}{$15.3 \pm 0$} & \multicolumn{2}{|c|}{$0 \pm 0$} \\
\hline Insecticide cost (field level) & $€ . h a^{-1}$ & \multicolumn{2}{|c|}{$715.2 \pm 0$} & \multicolumn{2}{|c|}{$0 \pm 0$} \\
\hline \multirow[t]{2}{*}{ Insecticide applications } & app.ha $a^{-1} \cdot$ year $^{-1}$ & \multicolumn{2}{|c|}{$2.56 \pm 0$} & \multicolumn{2}{|c|}{$0 \pm 0$} \\
\hline & & $\mathrm{MCB}$ & TAW & $\mathrm{MCB}$ & TAW \\
\hline Pest loss (regional level) & Million $€$ & $3 \pm 0.1$ & $3.9 \pm 2$ & $0.7 \pm 0$ & $8.8 \pm 3.7$ \\
\hline \multirow[t]{3}{*}{ Pest loss (field level) } & $€ . h a^{-1}$ & $142.6 \pm 3.8$ & $180.5 \pm 93.7$ & $21.9 \pm 0.5$ & $276.7 \pm 115.7$ \\
\hline & PMS 3 & & & & \\
\hline & Units & \multicolumn{2}{|c|}{ Conv } & & $\overline{B t}$ \\
\hline NPV (regional level) & Million $€$ & 18.9 & 2.2 & 209 & $5 \pm 3.5$ \\
\hline NPV (field level) & $€ . h^{-1}$ & 885.8 & 100.9 & 6551 & $7 \pm 108.3$ \\
\hline Insecticide cost (regional level) & Million $€$ & & & & \pm 0 \\
\hline Insecticide cost (field level) & $€ . h a^{-1}$ & & & & \pm 0 \\
\hline Insecticide applications & app.ha $a^{-1} \cdot$ year $^{-1}$ & & & & \pm 0 \\
\hline & & MCB & TAW & MCB & TAW \\
\hline Pest loss (regional level) & Million $€$ & $20.9 \pm 0.2$ & $4.1 \pm 2$ & $2.1 \pm 0$ & $9 \pm 3.7$ \\
\hline Pest loss (field level) & $€ . h a^{-1}$ & $978.5 \pm 8.1$ & $190.7 \pm 92.4$ & $64.3 \pm 1.1$ & $282.4 \pm 115.4$ \\
\hline
\end{tabular}

802 
805 Table V. Farmers' net present value (NPV) per hectare depending on the initial field of outbreak of 806 true armyworm (TAW). Results are shown for the first pest management strategy, i.e. insecticides used 807 in both conventional and $B t$ maize, in five different conventional/Bt proportions (means per Agricultural 808 System). It is assumed that TAW are introduced at a randomized location of favourable habitat. Nb field 809 indicates the number of outbreaks in the respective field.

\begin{tabular}{|c|c|c|}
\hline Fields & $\mathrm{Nb}$ fields & NPV (mean \pm sd) \\
\hline & \multicolumn{2}{|c|}{ PMR 1 - Scenario 1 (actual maize area) } \\
\hline Bt Maize & 3 & $5634.7 \pm 45$ \\
\hline Conv Maize & 4 & $5503.7 \pm 110$ \\
\hline Annual Crops & 23 & $5484.2 \pm 109$ \\
\hline \multirow[t]{2}{*}{ Rice } & 70 & $5520.4 \pm 89.6$ \\
\hline & \multicolumn{2}{|c|}{ PMR 1 - Scenario 2 (no $B t$ maize) } \\
\hline Conv Maize & 3 & $3837.7 \pm 102.3$ \\
\hline Annual Crops & 20 & $3717.1 \pm 81.9$ \\
\hline \multirow[t]{2}{*}{ Rice } & 77 & $3749.7 \pm 78.3$ \\
\hline & \multicolumn{2}{|c|}{ PMR 1 - Scenario 3 (Bt maize area reduced by $50 \%$ ) } \\
\hline Bt Maize & 3 & $4753.9 \pm 14.4$ \\
\hline Conv Maize & 3 & $4681.8 \pm 19.8$ \\
\hline Annual Crops & 27 & $4593.1 \pm 94.8$ \\
\hline \multirow[t]{2}{*}{ Rice } & 67 & $4623 \pm 93.3$ \\
\hline & \multicolumn{2}{|c|}{ PMR 1 - Scenario 4 (Bt maize area increased by $50 \%)$} \\
\hline Bt Maize & 5 & $6450.7 \pm 120.6$ \\
\hline Conv Maize & 1 & $6441.3 \pm N A$ \\
\hline Annual Crops & 17 & $6328.4 \pm 118.4$ \\
\hline \multirow[t]{2}{*}{ Rice } & 77 & $6384.5 \pm 223.7$ \\
\hline & \multicolumn{2}{|c|}{ PMR 1 - Scenario 5 (no conventional maize) } \\
\hline Bt Maize & 5 & $6722.1 \pm 196.6$ \\
\hline Annual Crops & 19 & $6627 \pm 112.6$ \\
\hline Rice & 76 & $6721.7 \pm 98.1$ \\
\hline
\end{tabular}

810 
Table VI. Comparison of the results for five different $B t$ maize adoption cases. Simulation results are shown as a percentage, considering of the actual Aragon land-use areas in PMS 1 (S1), insecticide used in both systems, using four different conventional/Bt proportions (means per Agricultural System). Comparisons for the total area invaded (TAI) by true armyworm (TAW), and the economic implications of predicated pest dynamics, after 25 years at field level, are shown. Table entries show the comparison (in \%) between the baseline scenario (S1) that represents the actual maize area for the year 2012 under the baseline pest management regime (PMS 1), i.e. with insecticides are used in both maize systems, and four other scenarios with different conventional/Bt maize proportions per agricultural system: S2, no $B t$ maize is cropped; S3, $B t$ maize area is reduced by $50 \%$; S4, Bt maize area is increased by $50 \%$ and; S5, all cropped maize is $B t$ maize. If the value equals zero, no change was noted.

\begin{tabular}{|c|c|c|c|c|c|c|c|c|c|c|c|c|c|}
\hline & \multirow{3}{*}{$\begin{array}{c}\text { TAI } \\
\left(\mathrm{km}^{2}\right)\end{array}$} & \multicolumn{3}{|c|}{ NPV $\left(€ . h^{-1}\right)$} & \multicolumn{6}{|c|}{ Economic loss to Pest $\left(€\right.$. ha $\left.^{-1}\right)$} & \multicolumn{3}{|c|}{ Insecticide expenditure $\left(€\right.$. ha $\left.^{-1}\right)$} \\
\hline & & \multirow[t]{2}{*}{ Conv } & \multirow[t]{2}{*}{$B t$} & \multirow[t]{2}{*}{ Mean } & \multicolumn{2}{|c|}{ Conv } & \multicolumn{2}{|c|}{$B t$} & \multicolumn{2}{|c|}{ Mean } & \multirow[t]{2}{*}{ Conv } & \multirow[t]{2}{*}{$B t$} & \multirow[t]{2}{*}{ Mean } \\
\hline & & & & & $\mathrm{MCB}$ & TAW & $\mathrm{MCB}$ & TAW & $\mathrm{MCB}$ & TAW & & & \\
\hline S1: PMS1 & 22685 & 3817.2 & 6651.7 & 5516.0 & 196.4 & 150.7 & 17.2 & 227.7 & 89.0 & 196.8 & 643.7 & 49.5 & 287.5 \\
\hline S2: $100 \%$ Conv & $-1.49 \%$ & $-1.88 \%$ & & $-32.10 \%$ & $6.92 \%$ & $-1.79 \%$ & & & $135.96 \%$ & $-24.82 \%$ & $0.00 \%$ & & $68.33 \%$ \\
\hline $\mathrm{S} 3:-50 \% B t$ & $-0.96 \%$ & $-0.48 \%$ & $-1.64 \%$ & $-16.21 \%$ & $2.34 \%$ & $-1.13 \%$ & $16.28 \%$ & $-7.77 \%$ & $64.86 \%$ & $-15.01 \%$ & $0.00 \%$ & $13.58 \%$ & $36.35 \%$ \\
\hline $\mathrm{S} 4:+50 \% \mathrm{Bt}$ & $1.89 \%$ & $2.04 \%$ & $0.15 \%$ & $15.69 \%$ & $-3.26 \%$ & $0.86 \%$ & $-33.14 \%$ & $5.40 \%$ & $-66.78 \%$ & $17.40 \%$ & $-55.38 \%$ & $-16.05 \%$ & $-51.41 \%$ \\
\hline S5: $100 \% B t$ & $4.24 \%$ & & $0.54 \%$ & $21.24 \%$ & & & $-40.12 \%$ & $14.19 \%$ & $-88.43 \%$ & $32.08 \%$ & & $-28.40 \%$ & $-61.10 \%$ \\
\hline
\end{tabular}

